\title{
WORKSHOP ON THE DEFORMATION OF THE WELLINGTON REGION
}

\author{
E.G.C. Smith, H. Anderson, et al
}

\section{PREFACE}

Euan Smith

Helen Anderson

The workshop was held in Wellington on September 19 and 20,1988 . It was preceded by a field trip on september 18 to look at the evidence of recent movements on the Wairarapa Fault, and followed by a similar trip to sites on the Wellington Fault on september 25. It was attended by 33 scientists and engineers interested in earthquakes, earth deformation and seismic hazard from Geophysics Division, NZ Geological Survey, Division of Land and Soil Science, Division of Water Sciences, and Physics and Engineering Laboratory of DSIR, Works and Development Corporation, and the Research School of Earth Sciences of Victoria University of Wellington. The purpose of the workshop was to determine the extent of existing data on the subject and then identify what new, feasible projects could fill gaps in the knowledge with an ultimate objective, among others, of enabling a refined estimate of seismic hazard in the region to be made. Those making presentations at the workshop were asked to provide in advance an abstract of their material that was as quantitative as possible, both to stimulate discussion and act as a permanent record of the workshop. It was judged that many of those attending would have been unable to provide full papers, and these were not sought. A good deal of the material has in fact been previously published, but it was felt that the consolidated Abstracts represented a very useful document for those interested in or working on the Wellington Region.

Two points must be stressed about the material in these abstracts. First, a number of the results are preliminary ones that are likely to be refined when the studies of which they are a part are completed. Readers who seek to use results that have not been published elsewhere would be well advised to consult the authors to see if there have been revisions. Second, it is appropriate within a workshop format to engage in a degree of speculation and suggest possibilities based on limited amounts of data. Discussion during a workshop may cause some authors to modify their ideas - indeed a workshop could be judged less than a success if this did not happen. Accordingly, authors were given the option of revising their abstracts in the light of new information or of withdrawing entirely if they felt for any reason that wider publication was inappropriate.

The following is a brief summary of projects proposed during workshop discussions.

\section{Geodetic/Interseismic Deformation}

1) Publish existing data from precise gravity surveys of the region that have been repeated and expand the precise gravity programme within the region so that the rate of change of level can be established.

2) Process and publish hitherto unpublished triangulation data.

3) Support the Global Positioning System project as proposed jointly by LamontDoherty Geological Observatory and various New Zealand institutions to measure deformation on a nationwide scale.

4) Repeat the Wellington to Castlepoint precise levelling survey, extended to the west coast (to Makara), and add a new leg to the south east coast, so that the uplift or subsidence between major earthquakes can be determined.

\section{Historical Studies}

1) Publish existing data on the 1855 earthquake - this project was identified as having the highest priority of all.

2) Extract all historical information on earthquake occurrence, particularly in the pre-instrumental period, and publish in summary form. (This has been done for the period to 1854 (G.A. Eiby: A descriptive Catalogue of New Zealand Earthquakes. Parts 1 and 2. NZ J. Geol. Geophys. 11: 16-40 and $16:$ : 857-907. The period 1855 to 1863 awaits completion of the 1855 study).

\section{Geological studies}

It was agreed that, as a minimum, the average return-times of earthquakes on the region's major faults had to be established. A major problem lies in finding suitable material at specific sites for dating movements. A variety of dating 
methods are potential supplements to the C14 method. Particular sites on the Wellington Fault that have been identified include: the terraces at Emerald Hill (Te Marua), the pond at Long Gully (trenching required), the identified fault trace offshore at Kaiwharawhara (drilling required). Some dates have been obtained and more are to be obtained from the Wairarapa Fault. A programme is needed to identify similarly suitable sites on other faults.

Resources for new programmes are currently very scarce. However, the announcement of the Earthquake Research Foundation, and the possibility that the Science and Technology Advisory Council would distribute funds for science projects on a competitive basis mean that there are distinct prospects that funds could be available for these projects in the not too distant future. The level of agreement on the need for these data should ensure that the projects will be in a strong position to bid for a share of research resources.

\section{TOTAL FAULT OFFSETS IN THE WELLINGTON REGION}

Dr Jim Ansell

Institute of Geophysics, Research School of Earth Sciences, Victoria University of Wellington.

on some faults in the Wellington Region it is possible to obtain average rates of movement in the recent past, from displaced and dateable features. If this were possible on all faults we would have an "initial value problem" with time increasing into the past. The current rates of movement could be projected into the past to examine the implications and consequences.

There are two significant problems. Firstly the knowledge of current rates is not in fact complete. Secondly there is a lack of knowledge of how rates varied in the past and of when the current faults were formed or reactivated.

An alternative approach comes from geometrical considerations of the overall relative movement of the Marlborough region, south of the Wairau Fault, and the Wellington Region. These considerations produce broad estimates of the general deformation.

For example, it appears that in the Wellington Region the east coast has moved south of the order of 150 kilometres relative to the west coast. It is not clear at present how this displacement is distributed between faulting, including movement on the steeply dipping bedding structures, and pervasive shear. Further, possibly earlier movement, between the west coast and the Marlborough Sounds is difficult to quantify.

Work is in progress to review and extend knowledge of structural features, volcanics and associated cherts and dove-grey argillites, etc to determine fault offsets across individual faults and to study general shear. 


\section{TIMING OF THE LAST LARGE EARTHQUAKE ON THE WELIINGTON FAULT IN THE SECTION TARARUA RANGES TO WOODVILLE (Work in progress)}

Sarah Beanland, New Zealand Geological Survey

Preliminary mapping along the Wellington Fault from its emergence from the Tararua Ranges northeast to Woodville has identified sites where the possibility exists to date the last movement on this section of the fault.

At Mangaroa Steam (Fig. 1) an alluvial fan is offset by a $1 \mathrm{~m}$ high scarp considered to represent only one faulting event. A radiocarbon sample collected from the fan alluvium provides a maximum age for the last fault movement of less than 250 yrs. At the Army Depot near Makomako a stream exposure reveals the fault plane where greywacke basement is faulted against fan alluvium which contains material dated at $318 \pm 36$ yrs. A more recent alluvial deposit has ponded behind the fault scarp and has also been sampled, but the date obtained is "post-bomb". These dates bracket the timing of the last event.

Preliminary assessment suggests that the last large earthquake on this section of the fault occurred between 250 and 150 yrs (ie immediately pre-historic), although the actual limits of the section are unknown. Detailed mapping of this fault section is planned to establish the length of rupture associated with this particular last earthquake, the size of the single displacement and associated earthquake magnitude, fault slip rate, and average recurrence interval.
RATE OF MOVEMENT AND GEOMETRY OF THE SOUTHERN SEGMENT OF THE WELLINGTON FAULT.

Kelvin Berryman,

N.Z. Geological Survey.

The Wellington Fault is one of the major active dextral strike-slip faults of southern North Island. Quaternary stratigraphic studies and fault mapping along the southern part of the fault have provided some data on rates and geometries.

Increasing numbers of loess units, separated by paleosols, on successively older fluvial terraces in the Upper Hutt and Kaitoke basins (Fig. 2) provide a means of estimating horizontal slip rates on the Wellington Fault. Horizontal offsets of channels on terrace surfaces and terrace risers range from $3.2 \mathrm{~m}$ to more than $900 \mathrm{~m}$. At Emerald Hill, a terrace with an estimated age of 15000 years, is dextrally offset by 104 metres (after correcting for tread width differences of the terrace on either side of the fault), an older terrace estimated to be about 70000 years old is offset by 440 metres and a 940 metre offset is associated with a terrace about 140000 years old. The 104 metre offset of the 15000 year old terrace is the best constrained and indicates a dextral sip rate of $7.0 \pm 1.6 \mathrm{~mm} / \mathrm{yr}$ (Fig. 3). Vertical movement rates on the fault are low, generally less than $10 \%$ of the horizontal rate. There has also been a change in the upthrow side of the fault; whereas earlier movement was upthrown to the northwest, since about 15 ooo years ago the fault has been upthrown to the southeast. A low-level sequence of terraces at $\mathrm{Te}$ Marua are appreciably younger than 15000 years and the smallest offset is $3.2 \mathrm{~m}$ dextral and $0.3 \mathrm{~m}$ vertical. Successively higher terraces or channels are dextrally offset by $3.7 / 4.7,7.4$, and $18.0 / 19.0 \mathrm{~m}$ (adjusted for tread width differences) and suggest single event dextral offsets of about $4.0 \pm 1.0 \mathrm{~m}$ and that the fault has moved with this characteristic amount of movement on the past 5 occasions.

Although the wellington Fault is characterised by 1 inear traces and strong linear continuity, significant bends and side-steps also occur. At Thorndon, the fault bends $18^{\circ}$ to the east and bends again by $10^{\circ}$ at Upper Hutt (Fig. 3). At Kaitoke, a $4 \mathrm{~km}$ right side-step occurs and the Kaitoke basin has formed in the resulting pull-apart structure. Insufficient data are available to determine the timing of latest rupture on the fault, or the extent of that rupture, although the right-step at Kaitoke may mark a segment boundary, in keeping with the $60 \mathrm{~km}$ length of the fault to the southwest and c. $4 \mathrm{~m}$ single event increments of faulting.

Increased efforts are needed to establish the timing of the latest movement on the fault and the locations and characteristics of segment boundaries. 


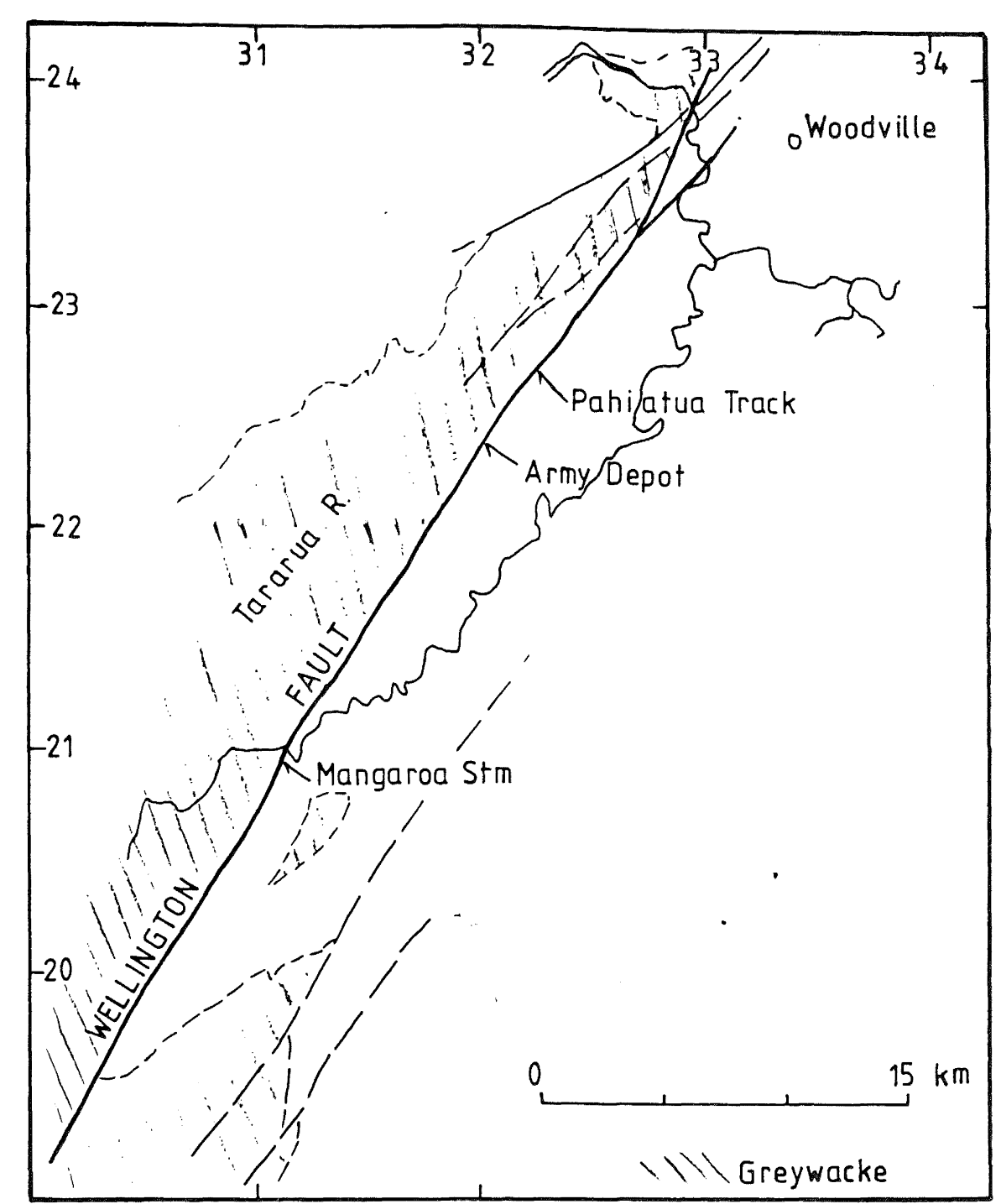

FIGURE 1. SKETCH MAP SHOWING SITES IMPORTANT IN THE STUDY OF THE WELLINGTON FAULT SOUTHWEST OF WOODVILLE.
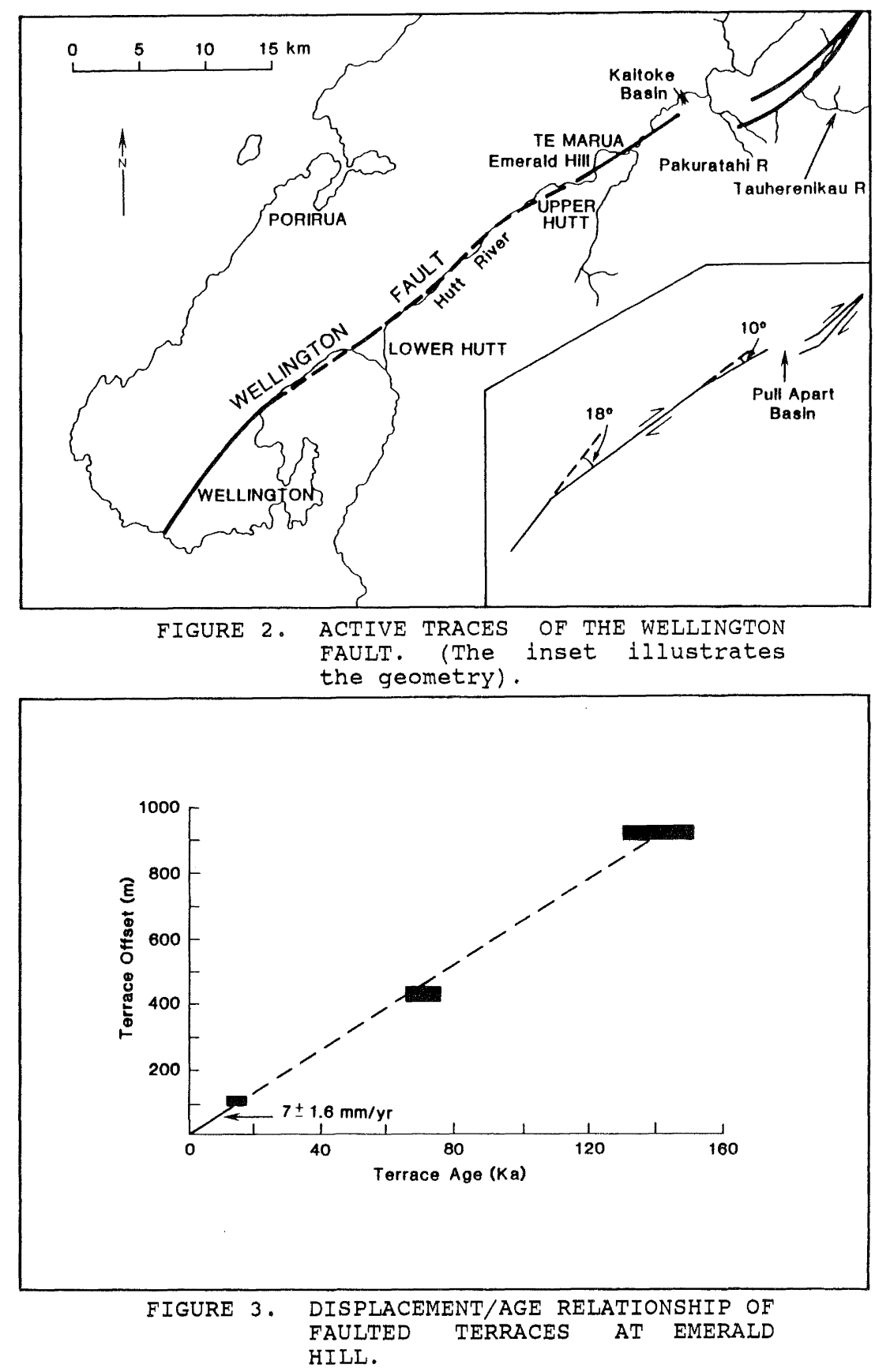

or 
GEODETIC OBSERVATIONS IN THE WELLINGTON REGION

Graeme Blick

N.Z. Geological survey, Lower Hutt

Geodetic networks within the Wellington Region enable the calculation of shear strains. A description of the various networks of different spatial extent and a summary of provisional results spanning different time periods for up to the past fifty years is presented.

The networks studied include:

A. Part of the DosLI lst order triangulation network (Figure 4), much of which was resurveyed in 1981 as part of the Castle Point - Karamea Earth Deformation Survey (Figure 5).

B. The Wellington Regional Monitoring Pattern (Figure 6), established by NZGS and incorporating Department of Survey and Land Information (DOSLI) stations. Surveys of this network have been made by DOSLI and NZGS. Incorporated into this network is the wellington Alignment, an alignment of marks installed to enable a rapid check on the deformation across the Wellington and ohariu Faults.

C. Small aperture fault monitoring patterns (Figure 7) established by NZGS and surveyed at regular intervals since 1969 .

Additional data is available from DOSLI 2nd, $3 r d$ and 4th order triangulation networks. Much of this data is being compiled ready for analysis.

The strain parameters have been calculated by Bibby's method using a simultaneous adjustment to compute the station coordinates and the shear strain (Bibby 1973 and 1982). The values quoted are the magnitude of maximum shear strain rate in engineering units and the azimuth of maximum relative contraction, each followed in brackets by the half width of it's $95 \%$ confidence interval. The analysis has been restricted to the use of horizontal angle data only. Additional distance data is available for most networks and this data is in the process of being analysed.

The results from the regional networks show a strain rate across the wellington region of approximately 0.5 ppm/yr maximum engineering shear, relatively contractional at 110 degrees (Table 1). Data from subsets of the Hutt valley Chain suggest a swing in the axis of contraction of the northern networks. The strain result from the Wellington Alignment for the period between 1971 and 1981 are intriguingly similar to the results from the Wellington Quad for a similar time period.
The results from the fault monitoring patterns (Table 2) are more variable, although there is some consistency in the results from the four networks along the wellington fault.

Bibby, H.M. 1973: The reduction of geodetic survey data for the detection of earth deformation. Report 84, Geophysics Division, DSIR.

- 1982: Unbiased estimate of strain from triangulation data using the method of simultaneous reduction. Tectonophysics 82 : 161-174.

Frank, F.C. 1966: Deduction of earth strain from survey data. Bulletin of the Seismological Society of America 56: 35-42.

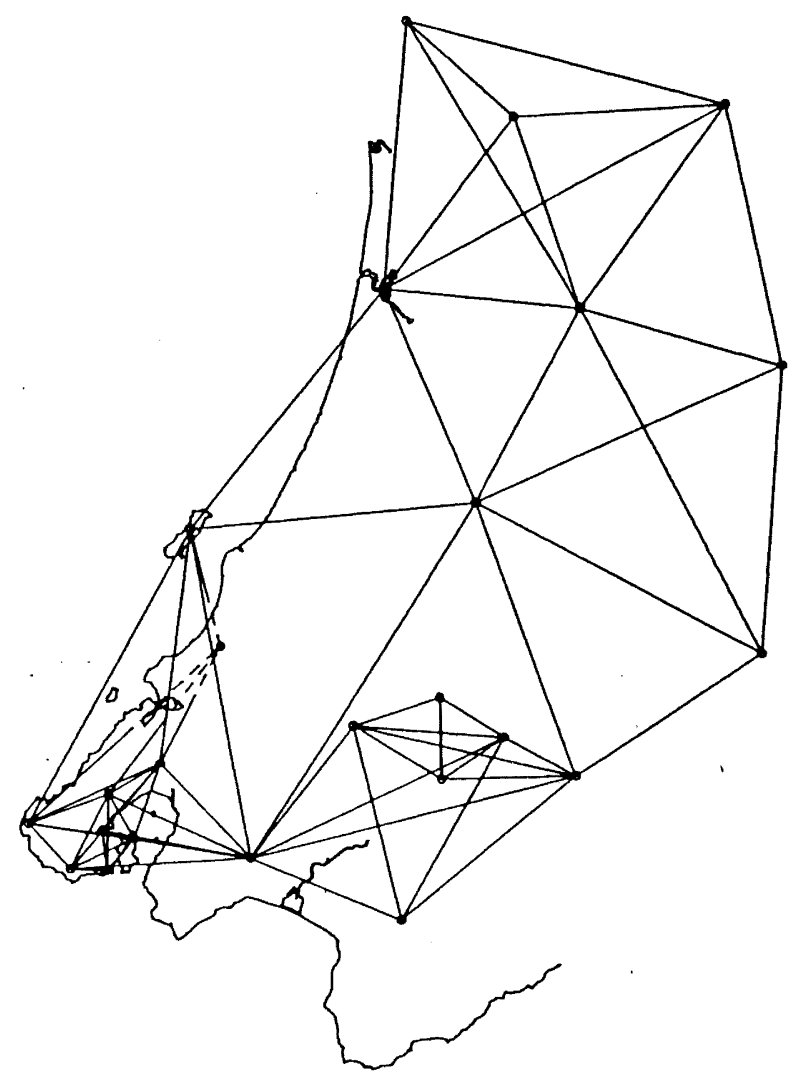

Geographic scale (km) 60

FIGURE 4. PART OF THE 1ST ORDER TRIANGULATION NETWORK SURVEYED IN $1928-30$. 


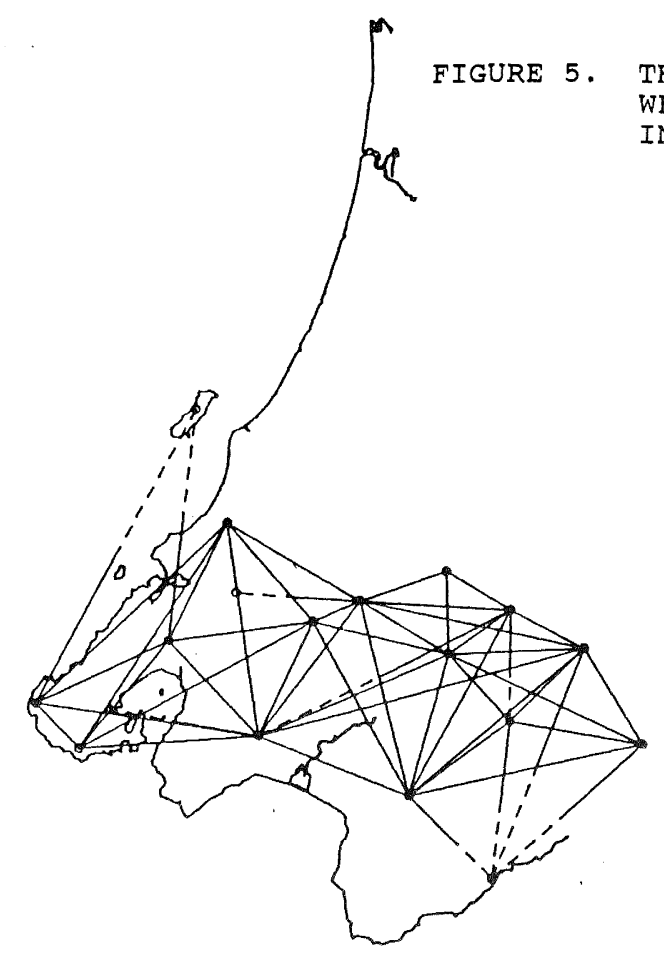
THE NORTH ISLAND SECTION OF THE
WELLINGTON-KARAMEA EDS SURVEYED
IN 1981.

FIGURE 7. LOCATION OF FAULT MONITORING

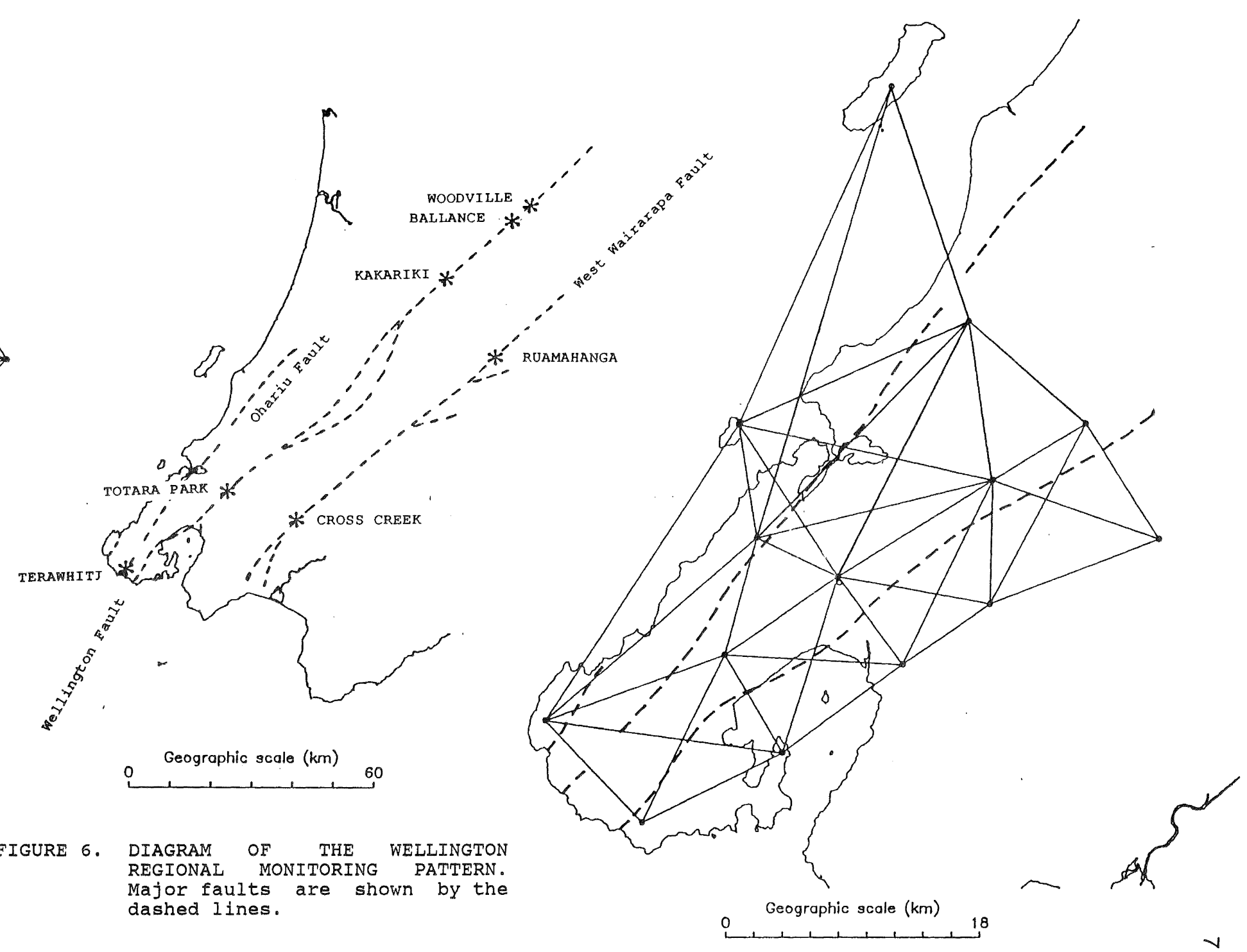


TABLE 1: SHEAR STRAIN RESULTS FROM REGIONAL NETWORKS

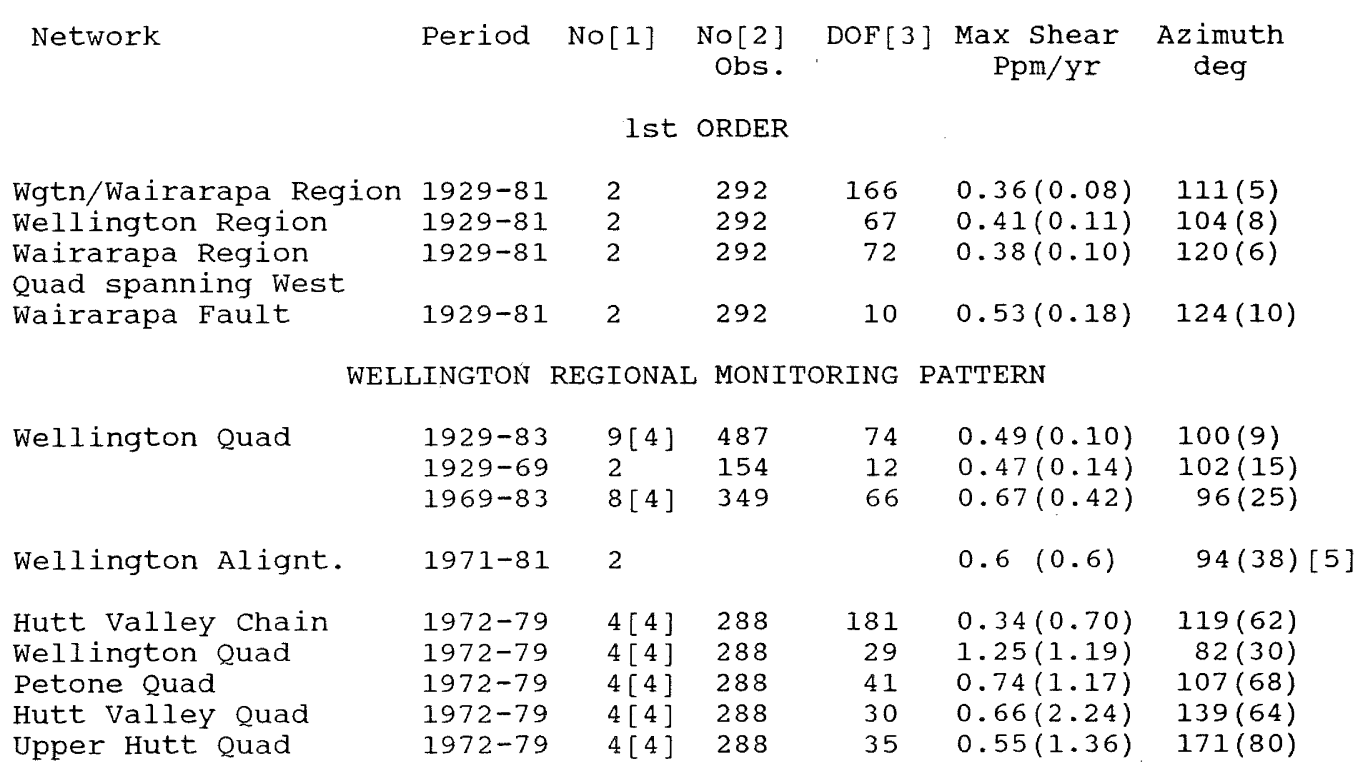

\section{TABLE 2 : SHEAR STRAIN RESULTS FROM FAULT MONITORING PATTERNS}

\begin{tabular}{|c|c|c|c|c|c|c|c|c|}
\hline Fault & Pattern & $\begin{array}{l}\text { strike } \\
\text { deg }\end{array}$ & Period & $\begin{array}{l}\text { No. } \\
{[1]}\end{array}$ & $\begin{array}{l}\text { No[2] D } \\
\text { Obs. }\end{array}$ & DOF [3] & $\begin{array}{c}\text { Max Shear } \\
\text { Ppm/yr }\end{array}$ & $\begin{array}{l}\text { Azimuth } \\
\text { deg }\end{array}$ \\
\hline hariu & Terawhiti & 40 & $1967-84$ & 3 & 157 & 103 & $1.11(1.39)$ & $163(15)$ \\
\hline ellington & $\begin{array}{l}\text { Totara Park } \\
\text { Kakariki } \\
\text { Ballance } \\
\text { Woodville }\end{array}$ & $\begin{array}{l}60 \\
40 \\
40 \\
40\end{array}$ & $\begin{array}{l}1974-85 \\
1969-81 \\
1973-82 \\
1975-82\end{array}$ & $\begin{array}{r}11 \\
3 \\
2 \\
2\end{array}$ & $\begin{array}{l}323(3) \\
172 \\
92 \\
36\end{array}$ & $\begin{array}{r}255 \\
112 \\
61 \\
18\end{array}$ & $\begin{array}{l}1.30(0.64) \\
0.91(0.47) \\
0.46(0.75) \\
1.01(0.96)\end{array}$ & $\begin{array}{l}140(10) \\
120(16) \\
133(43) \\
100(28)\end{array}$ \\
\hline t $W o$ & $\begin{array}{l}\text { Cross Creek } \\
\text { Ruamahanga }\end{array}$ & $\begin{array}{l}50 \\
40\end{array}$ & $\begin{array}{l}1969-83 \\
1969-75\end{array}$ & $\begin{array}{l}4 \\
2\end{array}$ & $\begin{array}{l}128(1) \\
70\end{array}$ & $\begin{array}{l}83 \\
41\end{array}$ & $\begin{array}{l}0.31(0.50) \\
0.75(2.37)\end{array}$ & $\begin{array}{l}54(41) \\
34(51)\end{array}$ \\
\hline
\end{tabular}

Computations have been made using the NZGS program 'ADJCOORD' version 4.04 .

[1] Number of Surveys.

[2] Number of observations. Number of rejected observations shown in brackets

[3] Degrees of freedom.

[4] 1979 Survey consists of two data sets (based on instruments used).

[5] Strain calculated by Franks method (Frank, 1966).

TABLE 3

\begin{tabular}{lrrlrcc}
\multicolumn{1}{c}{ Array } & $\begin{array}{c}\text { Aperture Period Surveys } \\
(\mathrm{m})\end{array}$ & & & $\begin{array}{c}\text { df[1] } \\
\text { Max shear[2] } \\
\text { ppm/yr[4] }\end{array}$ & $\begin{array}{c}\text { Azimuth[3] } \\
\text { deg[4] }\end{array}$ \\
Te Marua & 5 & $1982-88$ & 27 & 92 & $5.4(1.6)$ & $139(7)$ \\
Totara Park & 130 & $1974-85$ & 11 & 255 & $1.31(0.66)$ & $140(10)$ \\
Wgtn Quad & 10000 & $1929-69$ & 2 & 12 & $0.47(0.14)$ & $102(15)$ \\
& & $1969-83$ & 8 & 66 & $0.67(0.42)$ & $96(25)$ \\
HV Chain & 10000 & $1972-79$ & 5 & 147 & $0.44(0.62)$ & $112(47)$ \\
Wgtn Region & 28000 & $1929-81$ & 2 & 51 & $0.42(0.12)$ & $112(8)$
\end{tabular}

[1] Degrees of freedom in strain estimation

[2] Engineering shear

[3] Azimuth of relative contraction

[4] Parentheses enclose $95 \%$ confidence half-widths from small error formulae 


\section{IS STRAIN CONCENTRATING ABOUT THE WELLINGTON FAULT?}

\section{D.J. Darby}

NZ Geological Survey, DSIR, Lower Hutt

Deformation monitoring arrays with spatial apertures extending over three orders of magnitude provide evidence for a concentration of strain about the Wellington Fault. Nowhere else in New zealand is this type of comparison possible.

The smallest of these arrays is the Te Marua strainmeter of $5 \mathrm{~m}$ aperture. It consists of an array of steel rods, described in detail by Brown and wood (1983). The method of data analysis and possible systematic instrumental problems are discussed by Darby and Perrin (1986). The remaining arrays are survey networks with apertures from $130 \mathrm{~m}$ to $28 \mathrm{~km}$, (see figure 8). Standard analysis methods were used and the results obtained by $R$. williams (pers. com.) are similar to those reported by others at this workshop. The following table summarises results from all the arrays.

The Te Marua result may be affected by instrumental problems, but confidence in it is enhanced by the similarity of its orientation to that at Totara Park. Deceptively high strain rates can arise from a single strain event, or a systematic error mimicking strain, between two surveys being divided by a short time period. This cannot happen here because of the large numbers of surveys done within the shorter time periods. Conversely, the smaller confidence intervals associated with the results from only two surveys, over the longer time periods, may arise from the inability of those data to contain departures from the uniform strain rate model.

The better determined strain orientations show relative contraction at respectively 80 deg and 60 deg to the fault strikes at Te Marua and Wellington. The displacement rate across the Te Marua array is too small (of the order of tens of microns/yr to be called creep in the usual sense of fault creep. The strain rate varies approximately as the aperture raised to the power of -0.3 so that, for example, a tenfold increase in aperture corresponds to a halving of the strain rate. This variation cannot be due to slow fault creep confined to the gouge zone and an immediate interpretation is that the regional strain rate is greater nearer the Wellington Fault than farther from it. The data give no information about what proportion of the variation may be plastic (irrecoverable) or elastic (recoverable) strain. Furthermore, the possibility of strain inhomogeneities independent of faulting has not been tested; that is, no $5 \mathrm{~m}$ or $130 \mathrm{~m}$ arrays lie elsewhere within the larger arrays. Lateral variation of rigidity and plasticity of surface materials must be taken into account before these results can be interpreted in terms of stress.

\section{References}

Brown, I.R., Wood, P.R. 1983: Strain measurement across the Welington fault at Te Marua. In: Proceedings, Third South Pacific Regional Conference on Earthquake Engineering. Wellington, The New Zealand National Society for Earthquake Engineering: 509-518.

Darby, D.J., Perrin, N.D. 1986: Mechanical strain gauge measurements at $\mathrm{Te}$ Marua. Bulletin of the N.Z. National Society for Earthquake Engineering 19(2): 104-110.

FIGURE 8. DISTRIBUTION OF ARRAYS WITH RESPECT TO THE WELIINGTON FAULT. The locations of the Te Marua and Totara Park arrays are as shown, the Wellington Quadrilateral is the southwestern portion of the northeast trending Hutt valley Chain, and the larger array to the south is the Wellington Region array. The trace of the Wellington Fault is indicated by the dashed line.

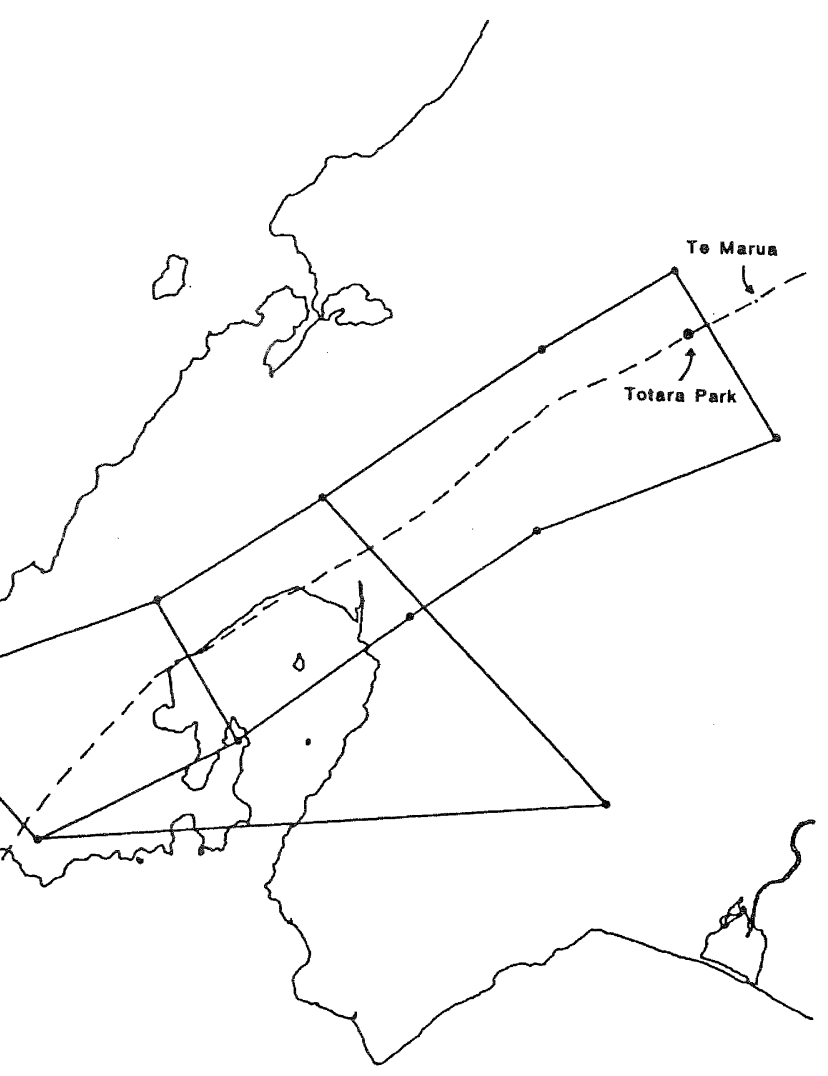




\section{5 - OBSERVATION AND INFERENCE}

George Eiby

Date and Time - Even the year has been questioned, but the date is established by contemporary press reports, letters, and diaries containing references to other datable events.

There are 25 or 30 reports of the time, most qualified by the word 'about', or giving an exact 5 or $10 \mathrm{~min}$. (not in itself a disqualification). No standard time existed, but Wellington Local Mean Time was generally observed. The time given by capt. Drury of the Admiralty survey ship 'Pandora' is close to the mean of the reliable reports, and seems likely to be an accurate observation. The preferred origin time is consequently $1855 \mathrm{Jan} 23 \mathrm{~d} 21 \mathrm{~h} 11 \mathrm{~m}$ Wellington Civil Time, or $23 \mathrm{~d} 09 \mathrm{~h} 32 \mathrm{~m} \mathrm{U} . \mathrm{T}$.

Isoseismals and Epicentre - The most distant felt reports come from Auckland, the ship 'Josephine Willis', Dunedin, and Gisborne, but the limits of the area within which the shock could have been felt are substantially farther away, judging from the deduced intensities. It is only close to Wellington that observations are sufficiently numerous for the isoseismals to be considered well-established (Figure 9) .

Accepting the uncertainties, a macroseismic epicentre close to the coast of Palliser Bay seems probable, and is consistent with the boundary of the known region of uplift, and the inferred faulting. A submarine epicentre is possible but cannot be inferred solely from the fact that a tsunami occurred.

Magnitude - The extent of the region of high intensity exceeds that of the Buller and Hawke's Bay earthquakes, and the radii of corresponding isoseismals suggest that the magnitude was not less than 8. Assuming the shock to have been a shallow event of Warwick Smith's Type A, a magnitude of 8.1 or 8.2 is probable. Numerous aftershocks are an indication of shallow origin.

Faulting - There are no indisputable observations. Supposed contemporary accounts do not match observable fault traces. Published estimates of the length of fresh surface breakage are improbably great.

Uplift - Best observations are at Muka Muka (9ft), and in Wellington Harbour (4ft). Claimed uplifts at Pauatahanui, Lowry Bay, and to the east of Lake Wairarapa are more reasonably attributable to silting. A shoal to the west of Ward Island is probably post-1855, but earthquake induced.

Tsunami - Good observations at Te Kopi, Rongotai, and Cape Terawhiti. 'Tidal' disturbances reported at Wellington are possibly small tsunamis accompanying aftershocks. South Island reports involve confusion with events in 1848 .
Landslides, Slumps etc. - Extensive landslides on both faces of the Rimutakas occurred northwards to Masterton and Bruce's Lagoon. Numerous slump cracks in flat areas of Wellington, Hutt valley, Wairarapa, and north to Otaki. Sand craters and liberation of ground-water in the same areas.

ISOSEISMALS

MODIFIED MERCALLI SCALE

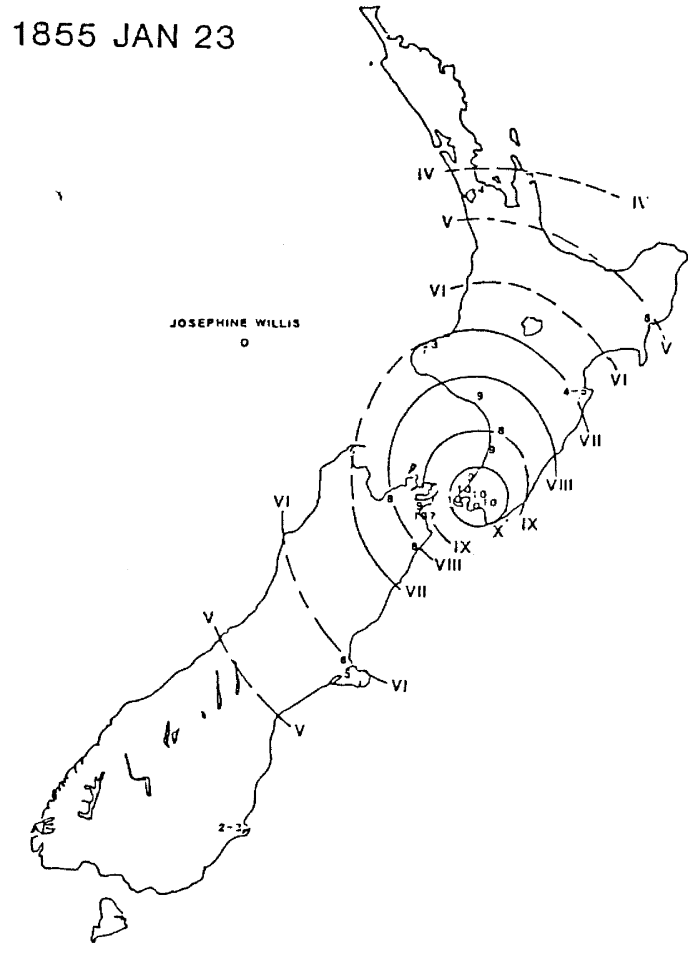

TIOMAL VEASION 1004 AUGUS

G.A.EIBY

FIGURE 9. ISOSEISMALS (MODIFIED MERCALLI SCALE OF THE 1855 JAN 23 EARTHQUAKE . 

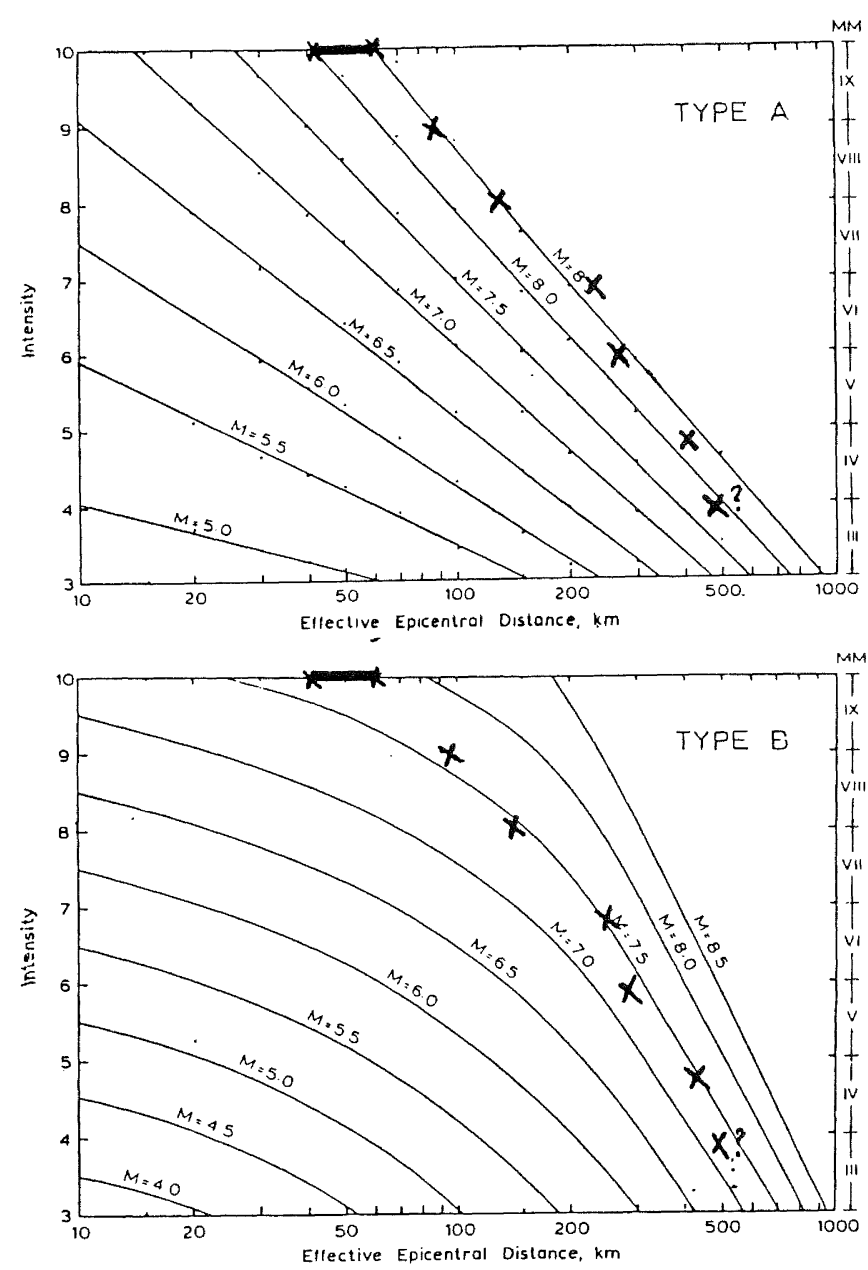

FIGURE 10. VARIATION OF MM INTENSITY WITH EPICENTRAL DISTANCE ( $X)$ PLOTTED AGAINST W.D. SMITH'S MODELS A AND B.
THE WELLINGTON FAULT IN THORNDON, ADDITIONAL INFORMATION SINCE 1977

Debbie Fellows

New Zealand Geological Survey

Mapping carried out for the compilation of the Wellington Late Quaternary Tectonic Map (Ota et al. 1981) was completed in 1977. It was based on air photo interpretation and measurements at key sites providing offset data with the main emphasis on the displacement of fan surfaces and other topographic features, e.g. streams, spurs.

since this time some site specific investigations have lead to the accumulation of additional fault location data. New topographic evidence results from good quality colour aerial photography flown in 1984 and some detailed field work. subsurface investigations have also been used. Figure 11 and the discussion below summarise the data.

At the northern end of Burnell Ave a $1.5-2 \mathrm{~m}$ high bank has been interpreted as a scarp of the Wellington Fault.

Drilling investigations carried out in 1976 along George st narrowed the location of the fault to between the middle drillholes, a zone some $35 \mathrm{~m}$ wide. This result could not be included on the published map but is shown here as a zone. Ground radar trials along Harriett st identified a feature likely to be a fault plane. A $3 \mathrm{~m}$ deep trench, within part of the building site there, exposed features which may be related to fault rupture but do not mark the position of the fault plane.

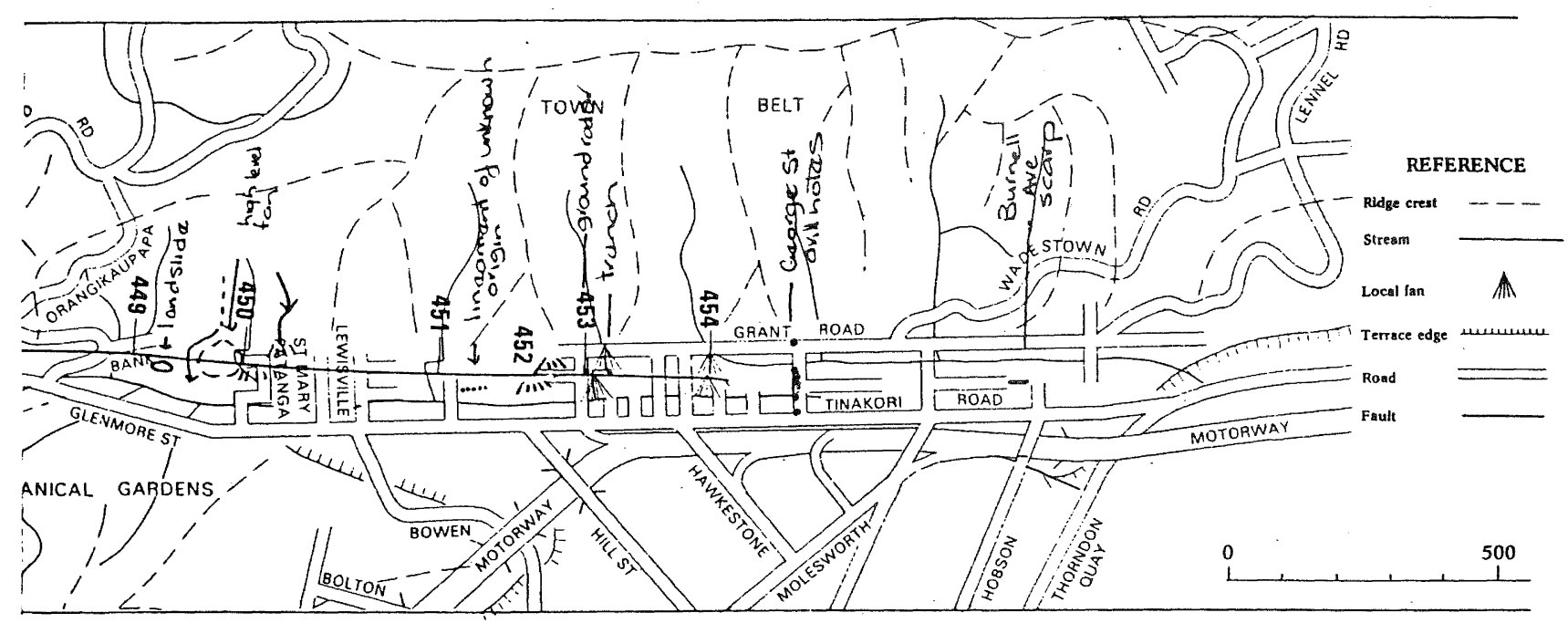

FIGURE 11. INSET C FROM THE PUBLISHED WELIINGTON LATE QUATERNARY TECTONIC MAP ANNOTATED WITH ADDITIONAL DATA. 
Interpretation of the 1940's and 1984 (colour) aerial photography has identified additional offset fan surfaces at Pitarua st (location 453) and Patanga Cres. and a lineament of unknown origin. A trace of the fault, not previously recognised, was clearly identified crossing the steep slopes near location 449. The headwall scarp of a small landslide, north of location 449, coincident with the fault giving the impression of a sharp continuous trace.

\section{References:}

Ota, Y.; Williams, D.N.; Berryman, K.R. 1981: Parts sheets Q27, R27 and R28 in Wellington lst edition. Late Quaternary tectonic map of New Zealand 1:50 000, DSIR.

\section{FIGURE 12 .} $\begin{array}{lrr}\text { ONE HUNDRED } & \text { AND } & \text { SIXTY-TWO } \\ \text { OBSERVATIONS } & \text { OF } & \text { DEXTRAL } \\ \text { DISPLACEMENT } & \text { AT } & \text { VARIOUS } \\ \text { LOCALITIES ON } & \text { THE } & \text { WELLINGTON } \\ \text { FAULT. } & & \end{array}$

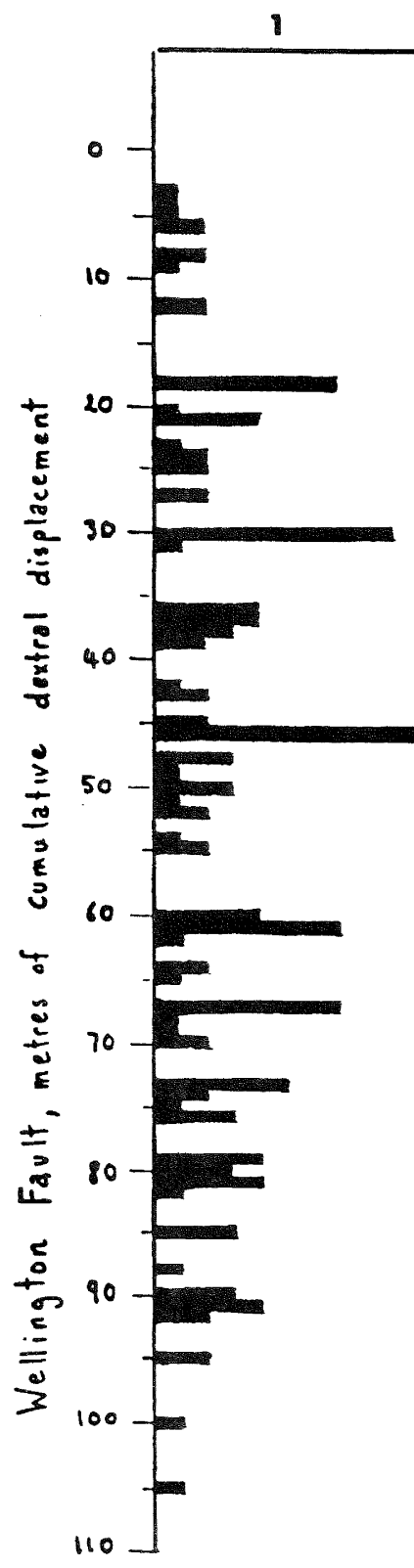

3456

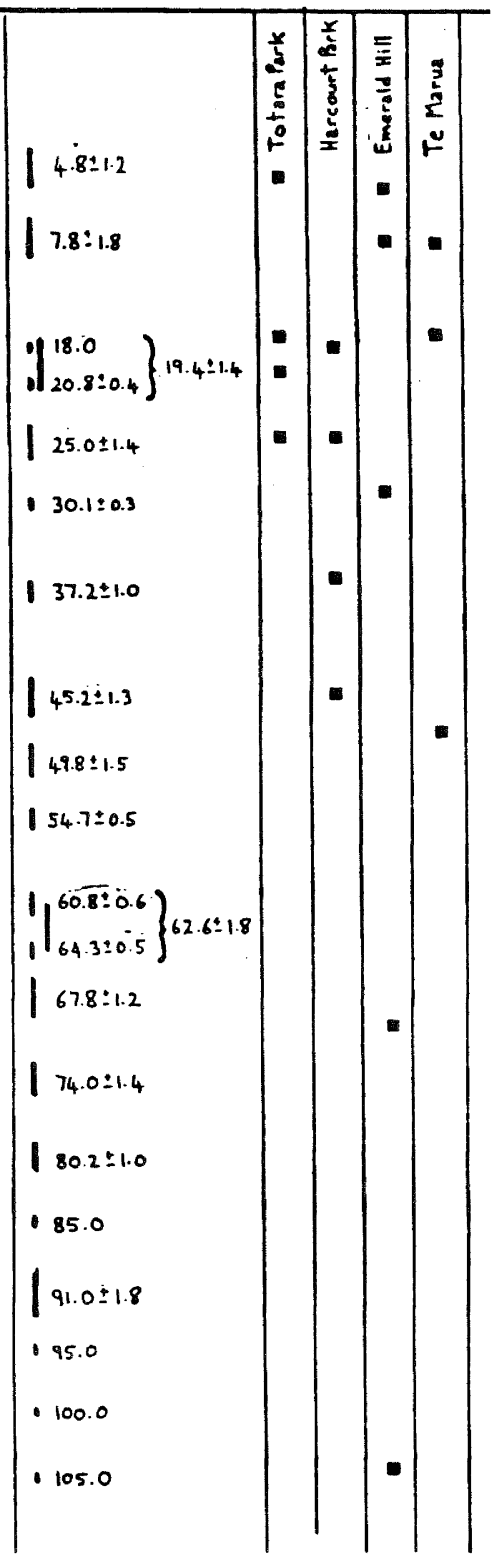

\section{PALEOSEISMICITY OF THE WELLINGTON FAULT}

Rodney Grapes,

Research School of Earth Sciences, Victoria University of Welington.

A total of 162 observations of dextral displacement over a fault length of $130 \mathrm{~km}$ (published data for the last 30 years) are shown as a histogram (Fig. 12) (column 1), and are averaged as 20 possible (18 probable) displacements (column 2). For comparison and control progressive river terrace displacements at single localities: Totara Park, Harcourt Park, Emerald Hill and Te Marua (Hutt River, Upper Hutt) are shown in columns 3 to 6 . For the interval back to $11 \pm 1 \mathrm{kyr}$ (the adopted age of the youngest, loess-free surface) there are 7 displacements all of which are recorded by the faulted terrace sequences.

The $11 \pm 1$ kyr surface is displaced by $45 \pm 1.3 \mathrm{~m}$ which gives an average dextral rate for the Wellington Fault of $4.5 \mathrm{~m} / \mathrm{kyr}$. For each earthquake the average displacement is about $6 \mathrm{~m}$. This is about half that of the Wairarapa Fault. Unlike the Wairarapa Fault there are no reports of movement on the Wellington Fault during the 1855 earthquake. The smallest and youngest displacement is $4.8 \pm 1.2 \mathrm{~m}$ but the data of the last earthquake is unknown.

\section{References}

Froggatt, P. and Hull, A., 1984. Aspects of Quaternary and Applied Geology of Wellington. Field trip tour guide, Geol. Soc. N.Z., 1984 Conference, Wellington.

Grapes,R., Hardy,E. and Wellman,H., 1984. The Wellington, Mohaka and Wairarapa Faults, pub. Geology Dept., Victoria University of Wellington, no. 29.

Lensen, G.J., 1958. The Wellington Fault from cook strait to Manawatu Gorge, N.Z. Geol. and Geophys., v.1, pp178-196.

Lensen, G.J., 1970. Sheet N153-Eketahuna, Late Quaternary Map of New Zealand 1:2M (1st edition), N.z. Geol. Surv. Misc. Series, Map 12, D.S.I.R., Wellington.

Lensen, G.J., 1973. Guidebook for Excursion A10 Central New Zealand, INQUA, 1973 pp2-24.

Lensen, G.J., 1981. Tectonic Strain and Drift, Techonophysics, v. 71 pp173-188.

Ota,Y., Williams, D.N. and Berryman, K.R., 1981. Parts sheets Q27, R27 and R28 in Wellington lst ed. Late Quaternary tectonic map of New Zealand, DSIR, Wellington. 


\section{THE WAIRARAPA FAULT: DISPLACEMENTS AND PALEOSEISMICITY}

Rodney Grapes,

Research School of Earth Sciences, Victoria University of Welington.

The Wairarapa Fault is best defined for $75 \mathrm{~km}$, from the western corner of Lake Wairarapa to Mauriceville where it mainly cuts Holocene river gravels overlying greywacke (see Figure 13). Although it appears as a continuous line on maps of $1: 250,000$ or smaller the fault is separated into a series of segments with constant strike by left stepped offsets of between $100 \mathrm{~m}$ and $500 \mathrm{~m}$ where bulges have developed. South-west of Lake Wairarapa the fault lies entireiy within greywacke and becomes more difficult to follow. However, it has been located at enough places along the forestcovered eastern foothills of the Rimutaka Range to indicate that it reaches the coast at the north-west corner of Palliser Bay. The fault continues out to sea for $13 \mathrm{~km}$ passing about $4 \mathrm{~km}$ east of Turakirae Head as indicated by a $360 \mathrm{~m}$, high submarine scarp. Beyond Mauriceville the Wairarapa fault is considered to join with the active Makuri Fault and extend north to The Bay of Plenty as part of the North lsland shear Belt.

From Palliser Bay to $2 \mathrm{~km}$ north of Mauriceville, a distance of $88 \mathrm{~km}, 78$ dextral displacements have been measured and can be averaged as 8 specific displacements (see Figure 14). The smallest and youngest range from $9 \mathrm{~m}$ to $13.5 \mathrm{~m}$ followed by a gap until the next set of displacements between $20 \mathrm{~m}$ and $25 \mathrm{~m}$. Dextral displacement during the last four earthquakes has been remarkably constant at $11 \pm 1 \mathrm{~m}$. The four older displacements average $22 \pm 6 \mathrm{~m}$ but may not represent all the earthquakes. The most extensive and youngest aggradation surface (the waiohine Surface) in the Wairarapa has been displaced by $120 \mathrm{~m}$ and $130 \mathrm{~m}$. The surface lacks loess cover and is dated at $11 \pm 1$ kyr which gives an average $11.5 \mathrm{~m} / \mathrm{kyr}$ dextral rate for the Wairarapa Fault since this time (see Figure 15).

Vertical displacement is erratic and is partly due to growing bulges on the upthrown side of the fault. For example, the throw of the Waiohine Surface varies from $20 \mathrm{~m}$ on the north-east slde of the waiohine River to om on the north-east side of the Waingawa River. An uplift rate can only be given for single localities where there is a sequence of progressively uplifted terraces, such as at waiohine River where the rate is $1.7 \mathrm{~m} / \mathrm{kyr}$. Mostly, the Wairarapa Fault is upthrown on the north-west side but at some localities north-east of Carterton Bush the south-east is upthrown.

During the 1855 earthquake the western side of Palliser Bay, i.e. west of the submarine continuation of the Wairarapa Fault, was uplifted $2.7 \mathrm{~m}$ resulting in the stranding of the then-forming beach ridge at Turakirae.
Contemporary accounts also indicate that vertical movement took place on the Wairarapa Fault for almost the whole length of the Wairarapa Valley. Because there were no fences or roads crossing the fault in 1855 no mention was made of any horizontal displacement. In fact the dominant dextral nature of faulting was not recognized until 1955. The smallest dextral displacements of $9 \mathrm{~m}$ to $13.5 \mathrm{~m}$ (mean $=12.1 \pm 0.5 \mathrm{~m}$ ) are both fresh and numerous enough to have occurred in 1855. Vertical displacement ranged from $2.7 \mathrm{~m}$ to $0.3 \mathrm{~m}$ and generally decreased to the north-east. Contemporary accounts of continuous uplift of $2.7 \mathrm{~m}$ along the fault for $144 \mathrm{~km}$ inland from the coast are therefore incorrect. The total on-land length of the 1855 fault break as a single well-defined feature is about $90 \mathrm{~km}$. Taking into account the onshore extension of the Wairarapa Fault and probable 1855 faulting northeast of Mauriceville makes $130 \mathrm{~km}$ the most probable rupture length.

Uplift at Turakirae and faulting along the Wairarapa Fault at Turakirae during large, (M8+) earthquakes such as that of 1855 clearly establishes a paired relationship that can be extended back in time. By simple enumeration the five earthquake uplifts of beach ridges at Turakirae (i.e. back to $6.5 \mathrm{kyr}$ - the age of the highest Holocene shoreline) correlate with the five youngest displacements on the Wairarapa Fault (Wellman,1972, Grapes and Wellman, 1987). The timing of the two

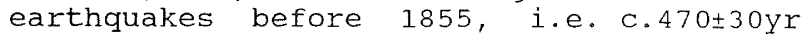
B.P. (the Haowhenua Earthquake of Maori tradition), and 3,340\$70 yr B.P. are fairly closely bracketed by ${ }^{14} \mathrm{C}$ dating; the oldest two are less well constrained and occurred sometime between 4.6-5.4kyr B.P. and $5.5-6.5 \mathrm{kyr}$ B.P. respectively.

To maintain the uniform dextral rate calculated from displacement of the $11 \pm 1$ kyr Waiohine Surface, either (1) the stillstand time between displacements is symmetrical with respect to the uniform faulting rate, or (2) each Earthquake displacement is symmetrical about the uniform faulting rate. Wellman (1967) used the former relationship to demonstrate the ages of the beach ridges at Turakirae and infer their uplift times. Two other cases using this step function are also possible: (3) where displacement is proportional to the time to the next earthquake, and (4) where time to the next earthquake is proportional to the displacement of the next earthquake. The relationship between time (back to $6.5 \mathrm{kyr}$ B.P.) and dextral displacement along the Wairarapa Fault indicates that the uniform dextral rate has been approximated by a combination of cases 1,3 and 4 .

\section{REFERENCES}

Best, E., 1918. The land of Tara and they who settled it. Journal of the Polynesian Society $27,49-71$.

Grapes,R., and Wellman,H., 1987. Paleoseismicity of the Wairarapa Fault.

Abstract, N.z. Geological society Conference. Dunedin. 
Grapes,R., and Wellman,H., 1988. The Wairarapa Fault. Research School of Earth Sciences Publ 4. 55pp.

Leach,F., 1984. The terminal age for the lower Wairarapa estuarine environment. Journal of the Royal Society of New Zealand, 14, 207-208.

Lyell, Sir Charles, 1856. Sur un Tremblement du Terre a la Nouvelle Zelande, du Janvier, 1855. Bull. Soc. Geol. Fr.. ser.2 (1855-1856), 13, 661-667.

McFadgen,B.G., 1980. Age relationship between a Maori plaggen soil and Moa-hunter sites on tbe west Wellington coast. N.Z. Journal of Geology and Geophysics, 23, $249-256$.

Moore,P.R., 1987. Age of the raised beach ridges at Turakirae Head, Wellington: a reassesment based on new radiocarbon dates. Journal of the Royal Society of New Zealand, 17, 313-324.
Moore,P.R., and McFadgen,B.G., 1978. Excavation of a shell midden at Turakirae Head, near Wellington, and a date for the Haowhenua earthquake of Maori tradition. Journal of the Polynesian Society, 87 , $253-255$.

Taylor, Rev.R., 1B55. Te Ika a Maui, or New Zealand and its inhabitants. Ist ed. Report by $E$.Roberts on the 1855 earthquakes in Appendix 2. Werthelm and Maclntosh, London.

Wellman,H.W., 1967. Tilted marine beach ridges at Cape Turakirae, New Zealand. Journal of Geosciences, Osaka City University, 10, 123-129.

Wellman,H.W., 1972. Rate of horizontal fault displacement in New Zealand. Nature, $237,257-277$

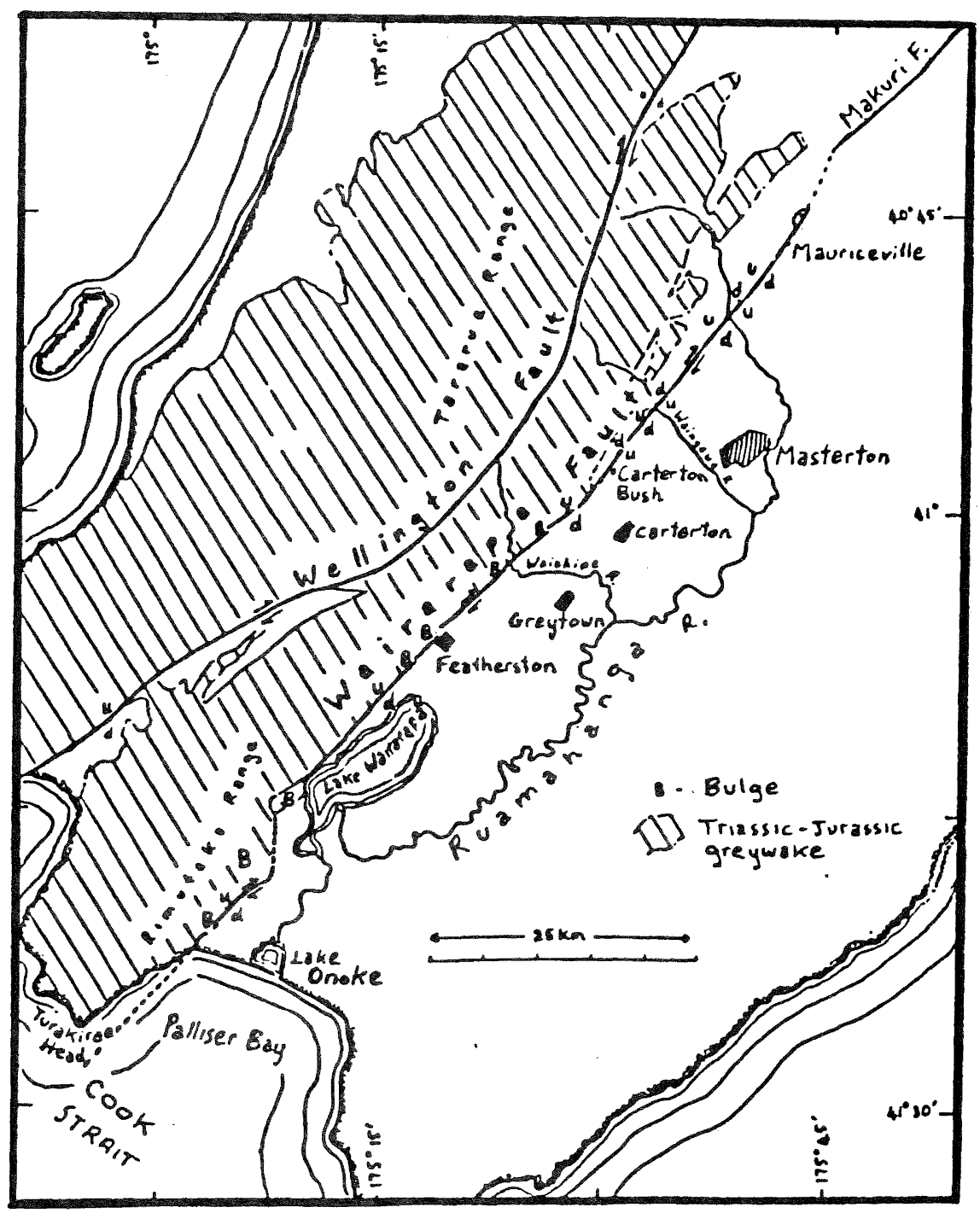




\section{K.B. Lewis}

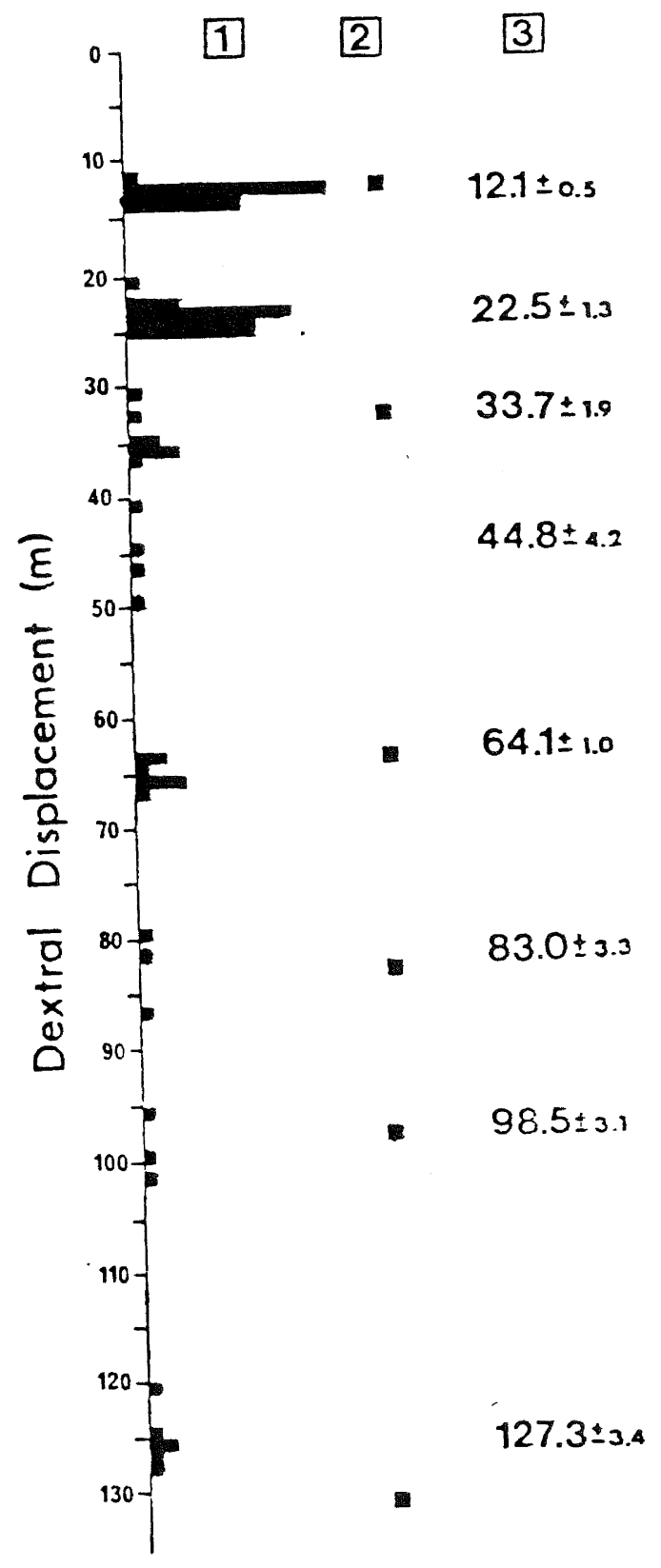

FIGURE 14 SEVENTY EIGHT OBSERVATIONS OF DEXTRAL DISPLACEMENT AT VARIOUS LOCALITIES ON THE WAIRARAPA FAULT.

Column 1. Histograms of displacements along the Wairarapa Fault from Palliser Bay to Mauriceville.

Column 2. Displacements at Waiohine River (Gapes and Wellman, 1988).

Column 3. Means of displacement greouplings \pm one standard deviation.
N.Z. Oceanographic Institute, DSIR, Kilbirnie, Wellington.

A high resolution seismic survey of the NW side of Wellington Harbour shows the most recent trace of the Wellington Fault crossing the coast in the vicinity of the Thorndon inter-island ferry wharf and lying 250-400m offshore between Kaiwharawhara and Ngauranga. Its trend is rotated about $10^{\circ}$ clockwise from the trend onshore in Thorndon (see Figure 16).

An early Holocene unconformity is vertically displaced by up to $6 \mathrm{~m}$ and younger horizons have moved lesser amounts. The trace is exposed at the seabed at Thorndon but buried by up to $3.5 \mathrm{~m}$ of undeformed sediment to the north. The displacement is upthrown on the southeastern (harbour) side. There is scattering of stratified reflectors close to the fault which is considered to be caused by freshwater leaking along the fault trace. 


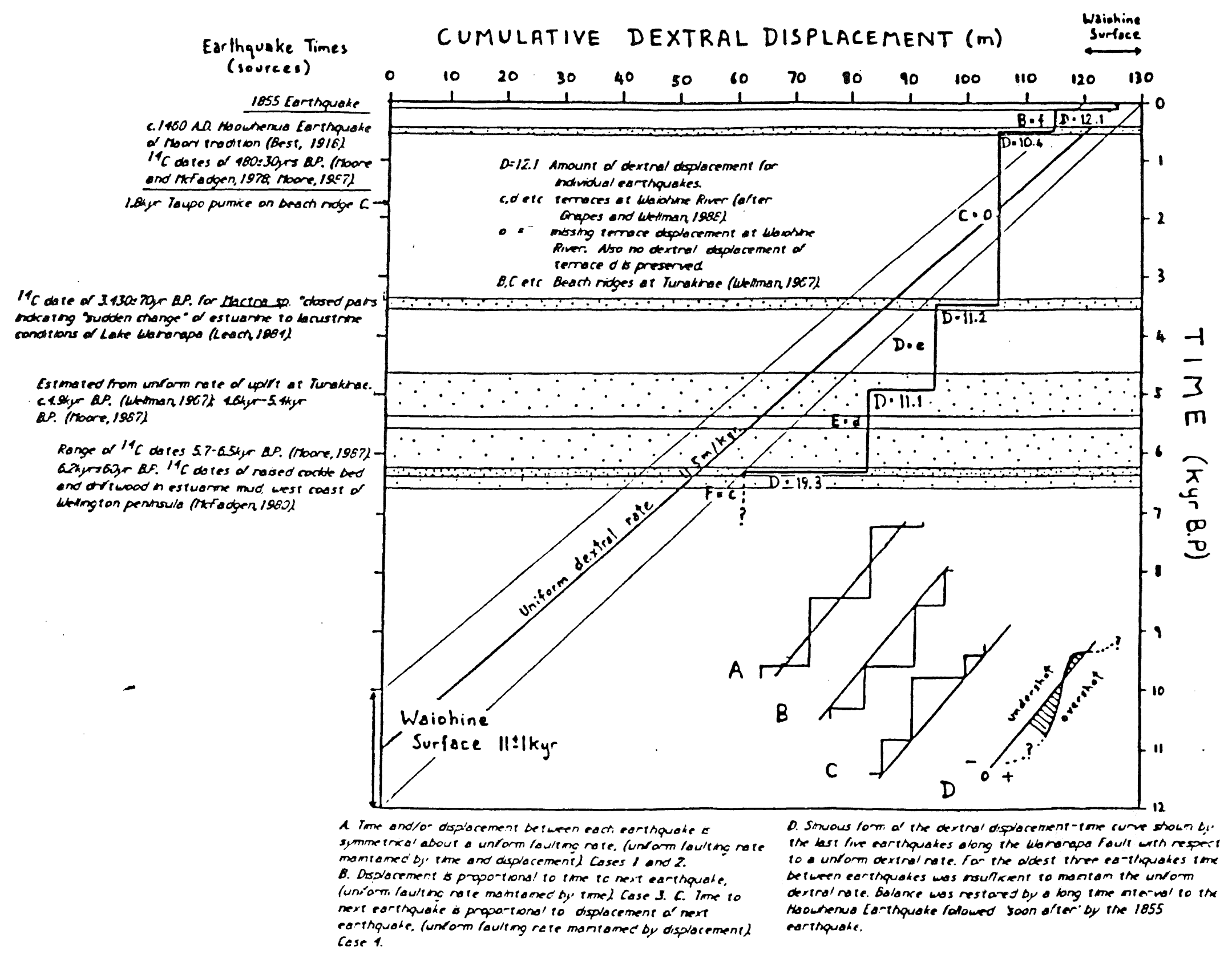

FIGURE 15. MODELS FOR RECURRENCE OF MOVEMENT ON THE WAIRARAPA FAULT. 


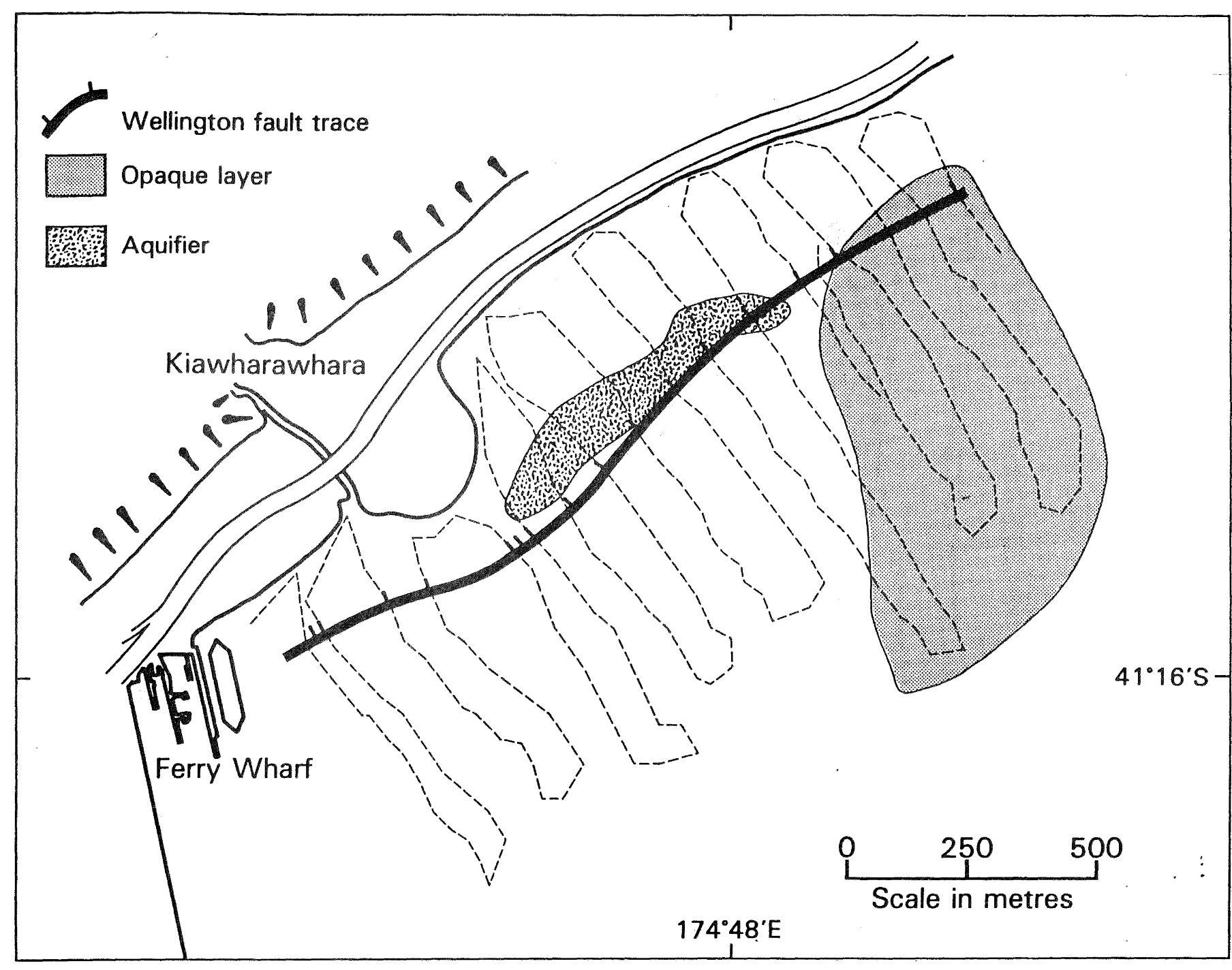

FIGURE 16. POSITION OF THE WELLINGTON FAULT IN WELLINGTON HARBOUR FROM SEISMIC SURVEYING. 


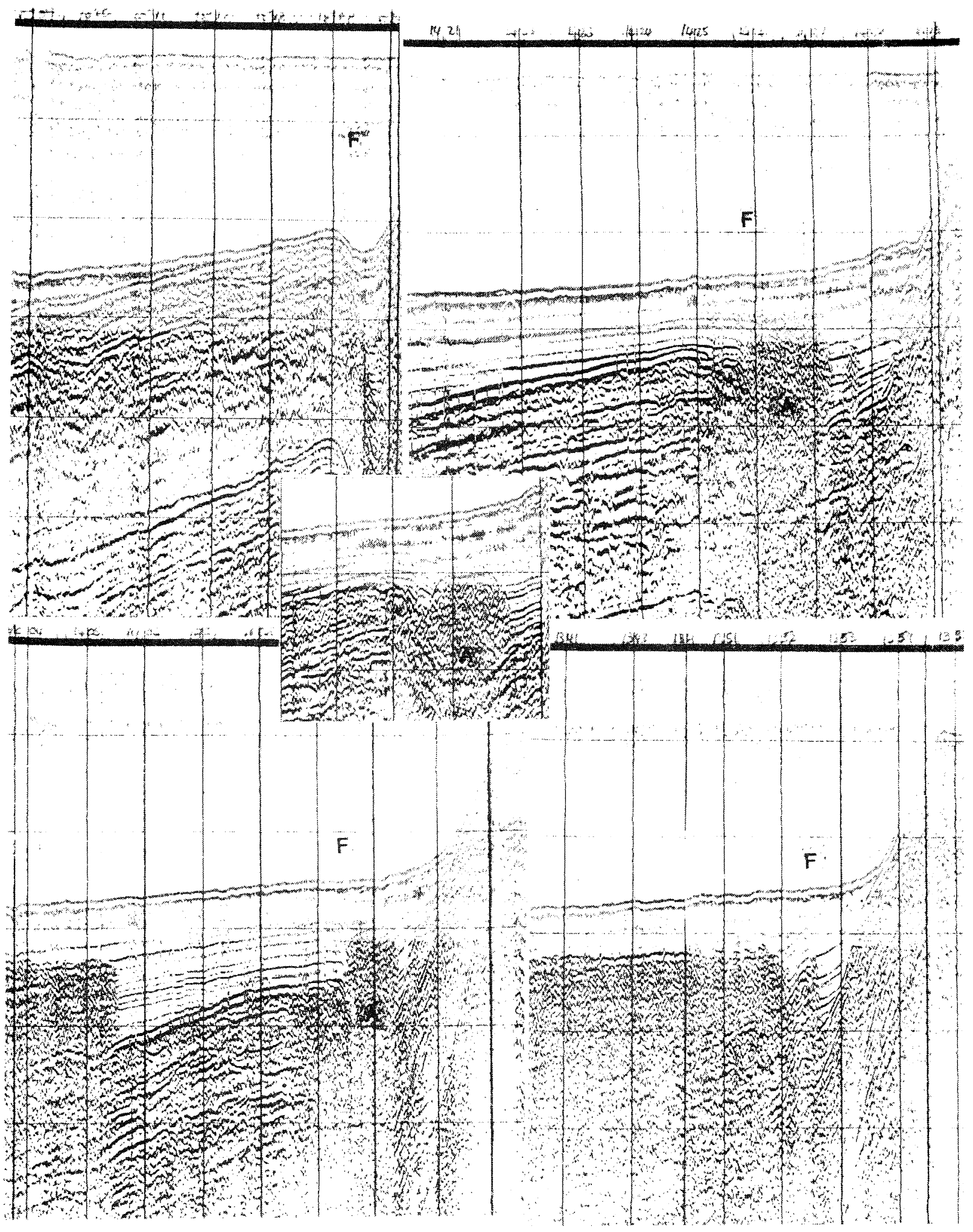

FIGURE 17. EXAMPLES OF SEIMIC REFLECTION PROFILES ACROSS THE WELIINGTON FAUIT (marked F) 
LOCATING SHALLOW FAULTS AND FRACTURE ZONES USING ENGINEERING GEOPHYSICS

Shona Mouton and Fred Smits

woRkS, Central Laboratories, Lower Hutt

\section{GENERAL}

Faults and fracture zones are often located using geological evidence. In most cases field observations would identify exposed crush zones or topographic expressions of the fault.

However, in many cases the geological evidence cannot be found. For instance, where sediments overlay the fault zone or in urban areas where topographic expressions have been removed by earth works.

In these circumstances engineering geophysical methods can be of great help.

Engineering geophysics cover a greater range of techniques, applied to a greater range of problems than any other branch of geophysics. The techniques are used for the detection of stratigraphic layers, ground-water flow, foundations, underground surfaces, and many other applications.

Annual turnover in engineering geophysics in the non-communist countries is estimated to be around $\$ 50$ million.

Geophysical measurements in themselves are unambiguous and precise. In their interpretation models of the geological structures have to be defined and there may be a number of models that fit the obtained data. To arrive at the most reliable model, several techniques should be used next and in addition to one another. Furthermore, all available site data should be included.

A well planned fault location survey should incorporate the following steps

1 Preliminary field work - topography

- geology

- historic

information

2 Analysis of data obtained under 1

3 Geophysical survey using most suitable techniques

4 Interpretation of geophysical data with recommendation for further field work

5 Further field work - drilling

- trenching

6 Geological and geophysical logging of 5

7 Reinterpretation of assumed model

8 Further geophysical or other field work

9 Final reporting
Not all steps are required, but the sequence outlined will give maximum information for available funding.

A list of the more common geophysical methods and their engineering applications are outlined in Table 4.

\section{METHODS}

The following methods are currently operated by Central Laboratories to detect faults or fracture zones.

\subsection{Seismic Refraction}

This method has been successfully applied in New Zealand to detect faults and fracture zones. Seismic compression waves (p-waves) are generated using sledge hammer blows or small explosions. These waves are refracted at subsoil layers with different densities and the wave arrivals detected at the surface using geophones. Layer thickness and P-wave velocities can be determined for each layer. In a simple two layer system calculations can be done manually. However, for more complicated subsoil conditions, advanced calculation methods and computer assistance will be required. Refer to Figure 18 for typical geophysical sections. Note low velocity zones normally identifying faults.

Resistivity is probably the oldest geophysical surface technique. Due to modern technology, eg signal enhancement through filtering and/or signal averaging (stacking) as well as current boosters, new interest in the techniques has developed. Especially so as computers can interpret the models fast and accurately.

commonly four electrodes are used in a line, two outer (current) electrodes and two inner (measuring) electrodes. Refer Figure 19.

Two techniques are used:

- Vertical Sounding, where deeper penetration in the ground is obtained by separating the electrodes in steps (depth penetration in the ground is around one third of distance between outer electrodes).

- Horizontal profiling, where a set of four electrodes is moved along the surface at fixed electrode spacing. This way the variation of soil resistivity along a surface line is obtained.

The location of near vertical surface faults may be determined by horizontal profiling. Fracture zones with adjacent weathered rock and fine textured materials are generally associated with a reduction in the resistivity measurements made when crossing the fault.

The magnitude of possible vertical offsets is investigated using vertical soundings taken parallel to the strike of the fault.

\subsection{Ground Probing Radar}

The ground probing radar is a high frequency ( 120 or $600 \mathrm{MHz}$ ) pulsed system. A 
transmitting antenna emits bursts of electromagnetic impulses at $50 \mathrm{~ms}$ intervals. Dependent on the sub-surface condition, transfer waves are reflected and received by another antenna. See Figure 20 .

Reflection depends on two physical properties of the strata: conductivity and dielectric constant. The conductivity affects the attenuation of the signal, while the dielectric constant affects the propagation velocity. Thus less conductive material like gravels, sands, silty sands, are very suitable for georadar investigation.

Sudden changes in sub-surface conditions, ie fault scarps, can be found. See Figure 21 .

\subsection{Geophysical Borehole Logging}

In areas with thick overburden, for example Lower Hutt, faults can be located from the detection of disturbed zones (trenching), or corre ation of stratigraphic layers on either side of the fault zone using boreholes.

For exact correlation of traceable layers, geophysical logging of the boreholes can be very advantageous. Most suitable are gammagamma, natural gamma logs, and electric logs.

In addition, recently Central Laboratories have developed a steel casing, which can be pushed into the soil up to $20 \mathrm{~m}$ deep using a $200 \mathrm{kN}$ hydraulic rig. Accurate geophysical logging through the casing can locate and identify traceable layers on either side of the fault.

The location where a vertical offset of the traceable layers occurs will represent the actual shear zone.

\section{CONCLUSION}

On many sites throughout the country engineering geophysical techniques have proven their ability to locate faults or fracture zones. A combination of geophysical methods together with trenching have identified these important geological features to a high degree of accuracy.
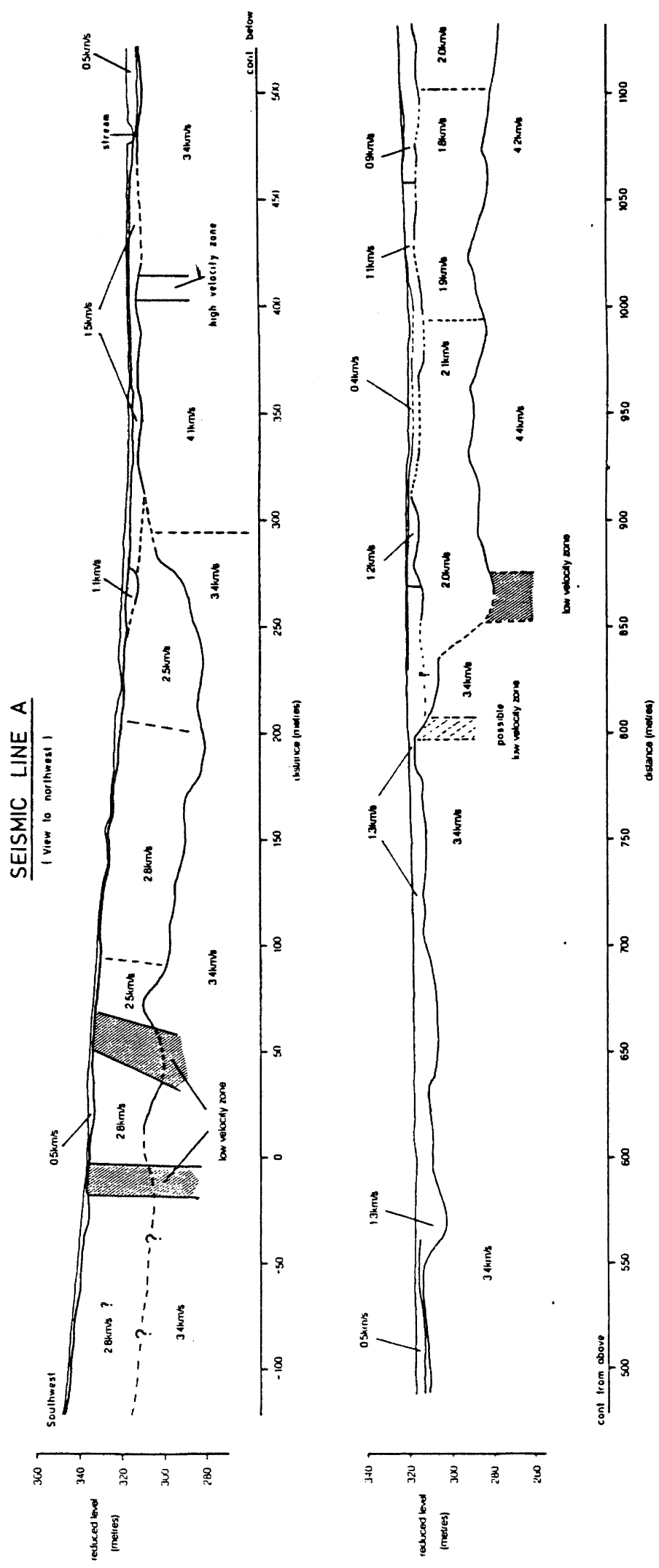
TABLE 4: USEFULNESS OF ENGINEERING GEOPHYSICAL METHODS

\begin{tabular}{|c|c|c|c|c|c|c|c|c|c|c|c|c|c|c|c|c|c|c|c|c|}
\hline $\begin{array}{l}\text { Georechnical } \\
\text { applications }\end{array}$ & 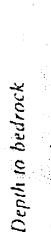 & 产 & $\frac{2}{\stackrel{0}{0}}$ & 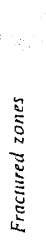 & 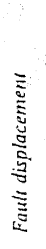 & 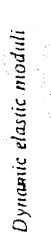 & 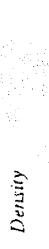 & 㣽 & 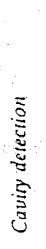 & 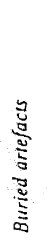 & 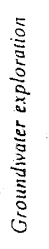 & 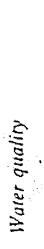 & 訚 & 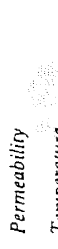 & 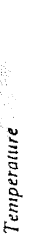 & 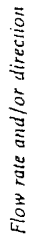 & 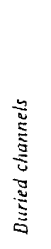 & 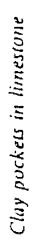 & 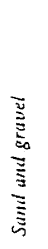 & 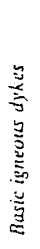 \\
\hline \multicolumn{21}{|l|}{ Seismic } \\
\hline$\star$ Refraction & 4 & 4 & 3 & 3 & 4 & 3 & 2 & 4 & 1 & 1 & 2 & 0 & 0 & 0 & 0 & 0 & 4 & 1 & 2 & \\
\hline eflection-land & 2 & 2 & 2 & 1 & 2 & 0 & 0 & 0 & 2 & 1 & 2 & 0 & 0 & 0 & 0 & 0 & 1 & 0 & 0 & \\
\hline Reflection-marine & 4 & 4 & 2 & 2 & 4 & 0 & 0 & 1 & 0 & 2 & 0 & 0 & 2 & 0 & 0. & 0 & 4 & 0 & 0 & \\
\hline *Cross-hole & 2 & 2 & 3 & 3 & 1 & 4 & 2 & 2 & 3 & 2 & 0 & 0 & 0 & 0 & 0 & 0 & 2 & 0 & 1 & 2 \\
\hline \multicolumn{21}{|l|}{ Electrical } \\
\hline${ }^{\star}$ Resistivity sou & 4 & 3 & 3 & 2 & 2 & 0 & 0 & 1 & 2 & 1 & 4 & 4 & 3 & 1 & 0 & 0 & 3 & 0 & 3 & \\
\hline $\begin{array}{l}\text { Induced polarization (IP) } \\
\text { Electromagnetic (EMI) and }\end{array}$ & 2 & 2 & 3 & 1 & 0 & 0 & 0 & 0 & 0 & 0 & 3 & 1 & 3 & 2 & 0 & 0 & 2 & 1 & 1 & \\
\hline ty profiling & 3 & 2 & 2 & 4 & 1 & 0 & 0 & 0 & 3 & 3 & 4 & 4 & 1 & 0 & 0 & 0 & 3 & 4 & 3 & 3 \\
\hline \multicolumn{21}{|l|}{ Other } \\
\hline *Grou & 2 & 3 & 1 & 2 & 3 & 0 & 0 & 0 & 3 & 4 & 2 & 2 & 1 & 0 & 0 & 0 & 2 & 2 & 1 & \\
\hline 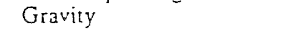 & 1 & 0 & 0 & 0 & 2 & 0 & 2 & 0 & 2 & 1 & l & 0 & 0 & 0 & 0 & & 2 & 1 & 1 & \\
\hline Magnetic & 0 & 0 & 0 & 0 & 2 & 0 & 0 & 0 & 2 & 3 & 0 & 0 & 0 & 0 & 0 & 0 & 1 & 3 & 0 & 4 \\
\hline \multicolumn{21}{|l|}{ Borehole } \\
\hline & 2 & 4 & 4 & 1 & 1 & 0 & 0 & 0 & 1 & 1 & 4 & 2 & 0 & 0 & 0 & 0 & 0 & 0 & 0 & 0 \\
\hline * Single point resistance & 2 & 4 & 4 & 0 & 0 & 0 & 0 & 0 & $\hat{0}$ & 0 & 4 & 2 & 1 & 0 & 0 & & & sena & 0 & 0 \\
\hline \multicolumn{21}{|l|}{ *Long \& short normal, and } \\
\hline * Natural gamma & 2 & 4 & 4 & 0 & () & 0 & 0 & 0 & 0 & 0 & $2 \mathrm{~A}$ & $\begin{array}{l}2 \\
2\end{array}$ & IA & $3 \mathrm{~A}$ & 0 & & 0 & 0 & 0 & 0 \\
\hline a-gamma & $3 \mathrm{~A}$ & 4 & 4 & 0 & 0 & 0 & $3 \mathrm{~A}$ & 0 & 0 & 0 & $2 \mathrm{~A}$ & 0 & $3 \mathrm{~A}$ & $2 A$ & 0 & 0 & 0 & 0 & 0 & 0 \\
\hline & $2 \mathrm{~A}$ & 4 & 4 & 0 & 0 & 0 & $3 A$ & 0 & 0 & 0 & $3 \mathrm{~A}$ & 0 & $3 \mathrm{~A}$ & 2 & 0 & 0 & 0 & 0 & 0 & 0 \\
\hline nductivity & 0 & 1 & 0 & 0 & 0 & 0 & 1 & 0 & 2 & 0 & 4 & 4 & 4 & 1 & 0 & 0 & 0 & 0 & 0 & 0 \\
\hline$\star$ Flui & 0 & 0 & 0 & 1 & 0 & 0 & 0 & 0 & 1 & 0 & 2 & 3 & 0 & 0 & 4 & 2 & 0 & 0 & 0 & 0 \\
\hline *Sonic & 3 & 4 & 2 & 3 & 0 & 3 & 2 & 1 & 2 & 0 & 1 & 0 & 1 & 0 & 0 & 0 & 0 & 0 & 0 & 0 \\
\hline
\end{tabular}

$0=$ Not considered applicable; $1=$ limited use: 2 =used. or could be used, but not best approach, or has limitations; $3=$ excellent potential but not fully developed: $4=$ gencrally comsidered an excellent appruach. techniques well developed; $A=$ in conjunction with other electric or nuclear logs.

* Equipment operated by WORKS, Central Laboratories.

Note: This table is reproduced by permission of the Geological society from the Report by the Geological Society Engineering Group Working Party in the Quarterly Journal of Engineering Geology, London, Volume 21 , 1988 .

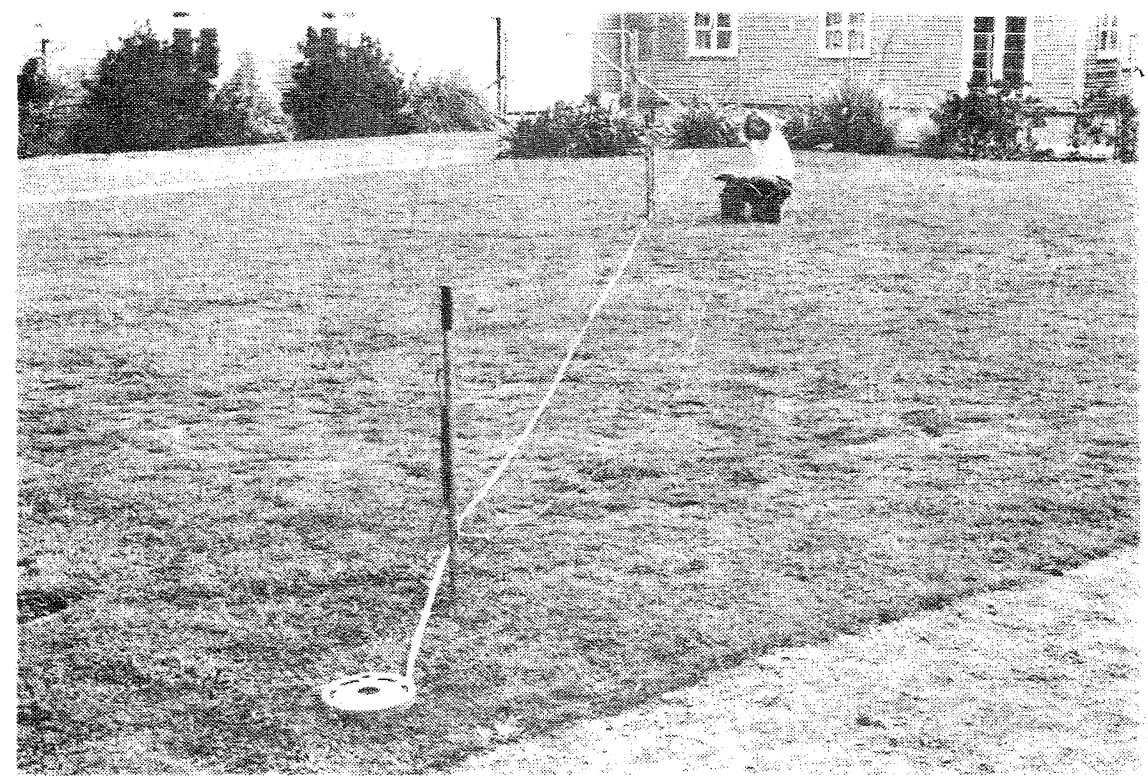

FIGURE 19. SETUP OF A RESISTIVITY SURVEY. 

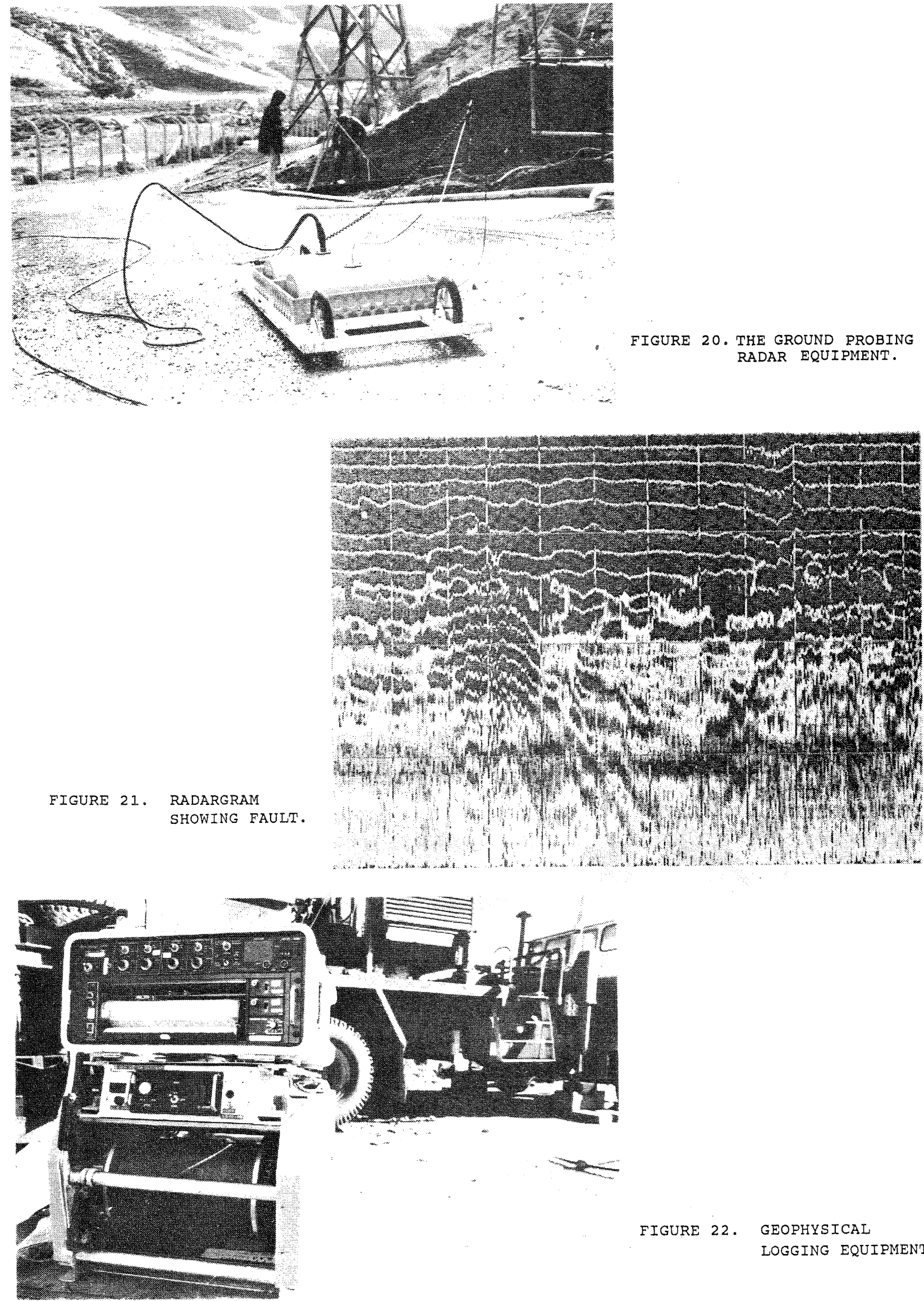

FIGURE 22. GEOPHYSICAI

LOGGING EQUIPMENT 
CRUSTAL STRAIN IN WELIINGTON FROM FIRST-ORDER GEODETIC MEASUREMENTS $1930-1980$

W I Reilly

Geophysics Division, DSIR, wellington. perturbations of a deformation ultimately derived from steady-state inter-plate movement.

\begin{abstract}
Wellington province was included in the Lands and Survey first-order geodetic triangulation (mesh size ca. $20 \mathrm{~km}$ ) in 1929-30; parts were resurveyed to comparable standards under the the Earth Deformation programme in 1980-81. The surveys thus span the Wairarapa Earthquake of 1942 in both space and time. The data, comprising both horizontal and vertical angles, astronomic azimuth, latitude, and longitude, and (for 1980-81) distance ratios from EDM measurements, have been adjusted using a three-dimensional spatial model which also incorporated time-variable parameters for combinations of (a) homogeneous shear strain, and (b) discrete displacement on a putative "wairarapa Fault" striking at $40^{\circ} / 220^{\circ}$, the deformation solutions being restricted to the horizontal sense.
\end{abstract}

The solution for the discrete displacement alone yielded an apparent movement of the south-eastern block of $(0.40 \pm 0.09)$ metre at an azimuth of $\left(282^{\circ} \pm 7^{\circ}\right)$, or a reverse thrust of $(0.35 \pm 0.09)$ metre and a rightlateral slip of $(0.19 \pm 0.06)$ metre (accuracy is given as 1 s.e.). The solution for homogeneous shear strain alone gave a (tensor) rate of $(0.20 \pm 0.02)$ microradian/year with the axis of maximum relative shortening at an azimuth of $\left(110^{\circ} / 290^{\circ} \pm 2^{\circ}\right)$. A joint solution for a model combining both distributed shear strain, and discrete displacement on the fault, yielded a virtually identical shearstrain rate; but the discrete displacement of $(0.08 \pm 0.05)$ metre was now not significant at 2 s.e.

The inferred shear-strain rate implies a total shortening, over $90 \mathrm{~km}$ of the triangulation network, and the 50-year time interval, of $(1.8 \pm 0.2)$ metre at an azimuth of ca. $110^{\circ} / 290^{\circ}$, assuming no extensional strain normal to this axis (i.e. approximately parallel to the presumed fault strike). This is about four times the magnitude of the discrete displacement obtained from the simple single-fault displacement model.

The unequivocal conclusion is that the Wellington region is undergoing (relative) compression on an ESE/WNW axis. Whether the deformation is viewed as a distributed strain, or as displacement on one or more discrete faults, cannot be resolved by a geodetic network of ca. $20 \mathrm{~km}$ aperture; but it appears that a model allowing displacement on a single fault only - the inferred 1942 wairarapa break - is by itself inadequate. More fault surfaces could be introduced, at the expense of increasing arbitrariness of the model, and increasing contravention of Ockham's razor. A continuum model subsumes all discrete motions, which can be viewed as 


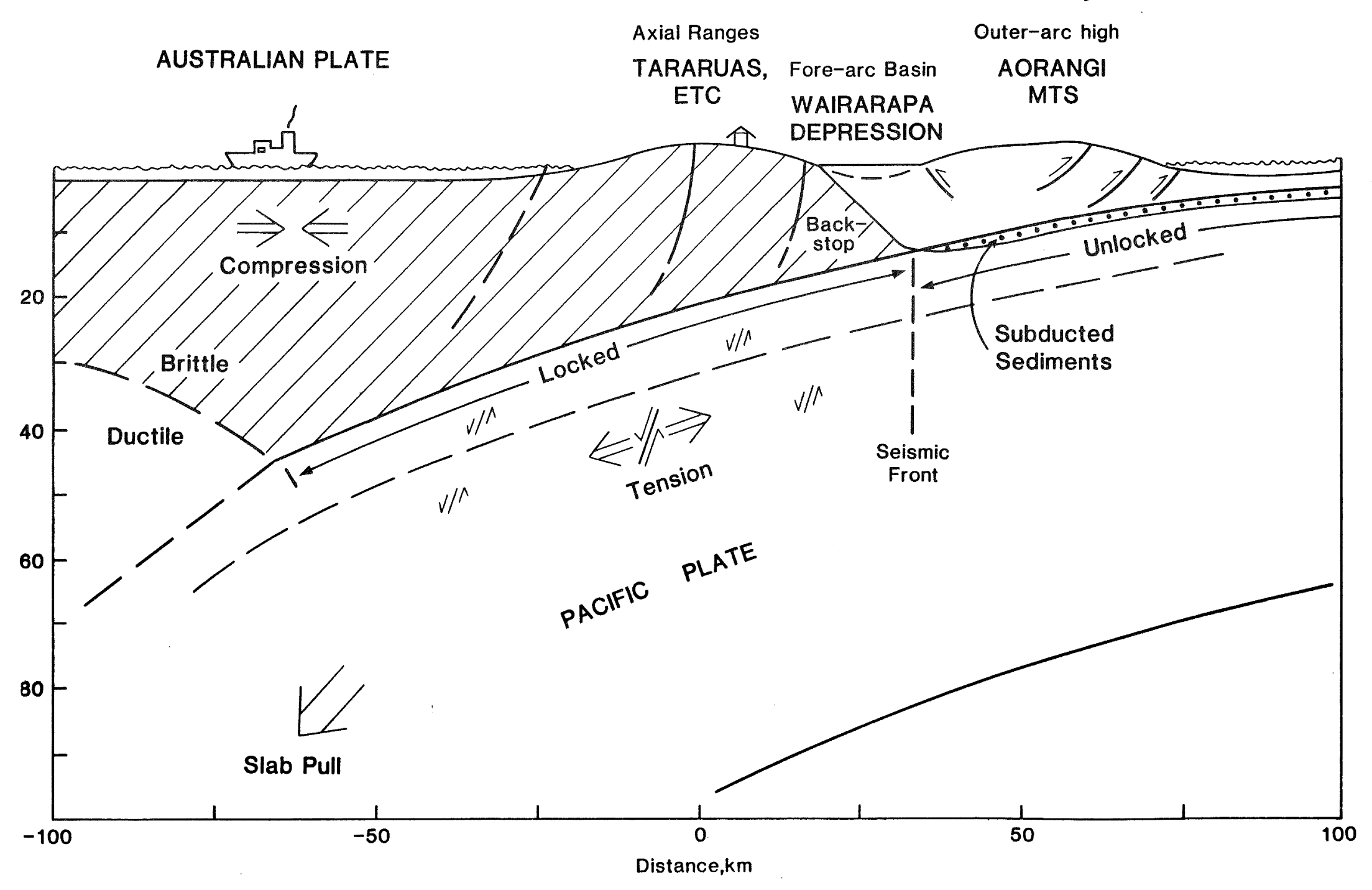

FIGURE 23. CARTOON CROSS-SECTION (NW-SE) ACROSS WELLINGTON SHOWING STRUCTURE INFERRED FROM SEISMOLOGICAL STUDIES. 
IMPLICATIONS OF SEISMICITY FOR THE TECTONICS OF THE WELLINGTON REGION

Russell Robinson

Geophysics Div. DSIR

Over the past decade it has been possible to determine accurate hypocentres and focal mechanisms of earthquakes in the Wellington region. These should reflect the current state of the collision/subduction process. By comparing these data (and also topography and geology) to data from theoretical and laboratory models of subduction zones, and to data from other regions with a longer record of the seismicity, some inferences about the mechanical properties can be made. Despite the complications due to oblique convergence and plate segmentation across cook strait, an attempt to do this for the southernmost North Island is shown in Figure 23. This figure can also be used as a transparent overlay for superposing on the "cross-section" of seismicity (1978-1985) in Figure 24. Note that the topography in Figure 23 is exaggerated and schematic only but there is no other vertical exaggeration. The topography of the region is quite similar to that of a typical "tightly coupled" subduction zone (as indicated by the terms in quotes), as are the seismicity within the subducted Pacific plate and the focal mechanisms. These features can be reproduced by models of subduction driven by "slab pull" and in which low strength subducted sediments are progressively dewatered and hardened (and perhaps partially underplated) as they progress down dip. Large earthquakes can occur on the "locked" part of the plate interface where "hard" rocks are in contact and friction is sufficient to allow elastic strain to accumulate. Faulting in such earthquakes would probably splay upward through the "accretionary border" on one or more faults (as for the 1946 Nankaido event in Japan) rather than extending to the trench. If such plate interface events occur, it is not clear if they would relieve the component of strain parallel to the plate boundary (the strike-slip component) as well as the perpendicular (thrust) component. Down-dip "corrugations" and offsets in the plate interface may inhibit motion in the parallel direction, this strain being relieved on the major strike-slip faults in the overlying Australian plate. on the other hand, if faults such as the Wairarapa and Wellington fault dip westward at depth, some fraction of the thrust component could be relieved by major events (1855?) on them. In any case, regional geodetic data (shortening in a roughly east-west direction), focal mechanisms of events in the Australian plate (east-west compression axes), and the lack of a significant number of small thrust events on the plate interface suggest that the plate interface is indeed locked. A problem with this model is that it predicts that wellington should be subsiding rapidly (about $8 \mathrm{~mm} /$ year by comparison to SW Japan) but tide gauge data (since 1900) indicate a much lower rate (1-2mm/year relative to Auckland). However, the exact rate of subsidence expected depends critically on the position of Wellington relative to the locked area and on the elastic (and inelastic) properties of the region which are not known very well. Leveling data extending from Wellington to the east coast would be very valuable but there is apparently little prospect that the existing Lands \& Survey lines will be releveled. Micro-gravity surveys are more likely to be repeated.

Examination of the seismicity, and other geophysical parameters, in more detail reveals significant changes with time that probably reflect changes in the internal stress state of the subducting Pacific plate. In addition to the changes reported previously (rate of activity, b-value, scattering properties, radon emission) new results on changes in the distribution of events in the subducting plate and (??) seismic velocity confirm an "event" of some sort in mid 1981. The cause of this event is not yet known. Such events may be important in triggering, or inhibiting, large events on the plate interface.

A major question posed by the distribution of seismicity in figure 24 is why the region between the wellington fault ( 0 on the horizontal distance scale) and the northward extension (?) of the Wairau fault (-30; near Kapiti Island) is quiet. It is important to know if this is a recent change in the seismicity from a more uniform distribution of events (a seismic gap of the 2nd kind). A short-term microearthquake survey several years prior to the establishment of the wellington network found a larger rate of activity in this region. Work is in progress to try to use data from the national seismograph network to answer this question. However, the large station spacing makes depth determinations uncertain you can't reliably distinguish Australian plate events from those in the underlying Pacific plate). This is a good argument for the continued operation of the Wellington Network! 


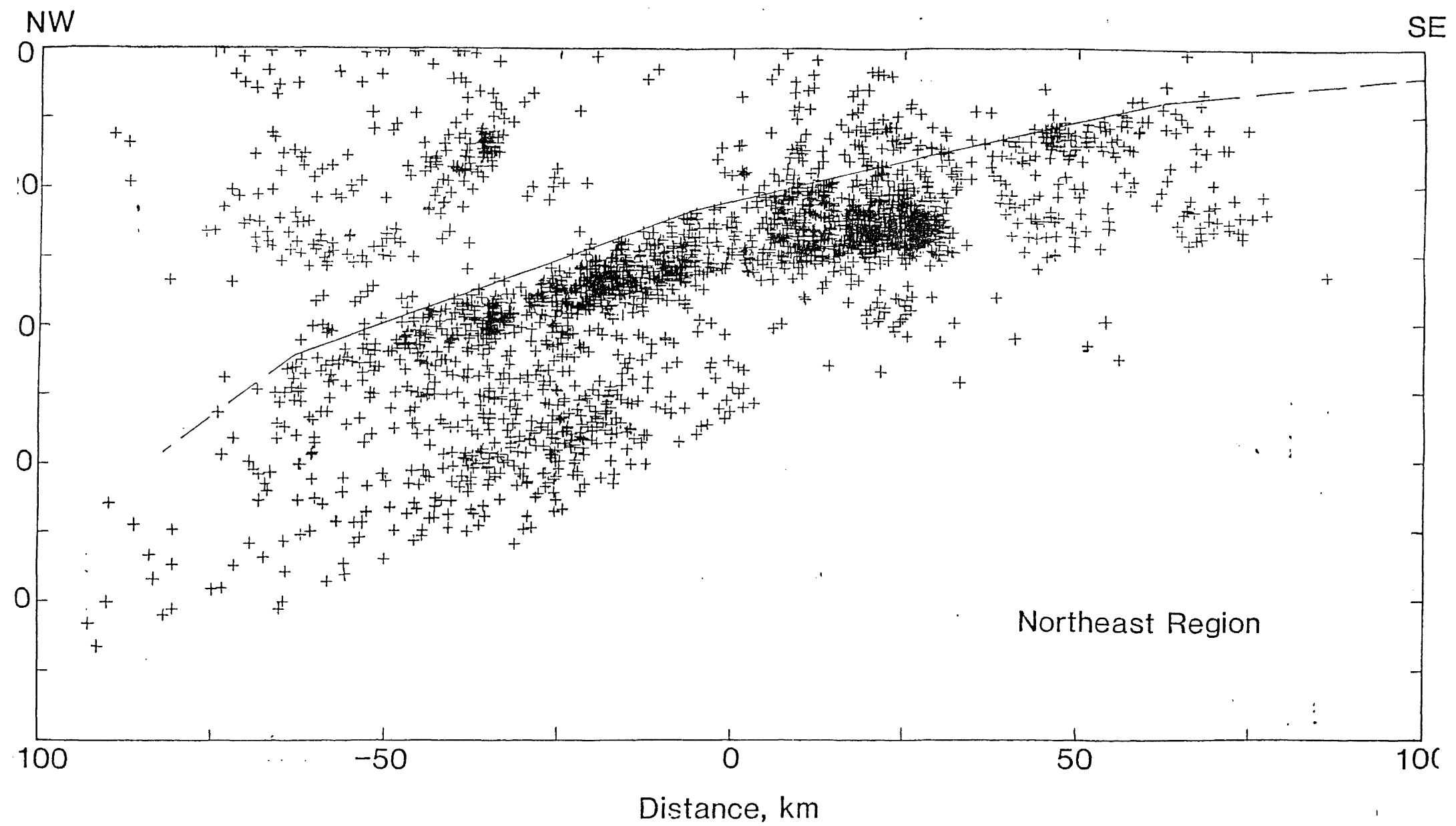

FIGURE 24. PROFILE OF SEISMICITY (+ = EARTHQUAKE) IN THE REGION NORTH-EAST OF COOK STRAIT. The position of the interface between the subducting Pacific plate andion and faulting plate (line the earthquake. 
WHAT IS THE RELATIONSHIP BETWEEN THE FAULTS OF THE WELLINGTON REGION?

Euan G C Smith

Geophysics Division, DSIR

At least four major, dominantly strikeslip, faults transect the Wellington Region which is also underlain by subducting Pacific Plate lithosphere. In other subduction zones, very large thrust earthquakes occur on the interface between the subducting plate and overlying material, and so the occurrence of such thrust events must be considered a possibility at wellington. The questions arise: What is the relationship between movements on these various faults? What is the physical coupling between them? How does this relationship affect assessment of earthquake hazard in Wellington?

The historical record is too short to establish the relationship directly, so inferences must be drawn from what information there is, building on some assumed physical model for strain accumulation and relaxation in wellington. The data include information on the nature of the larger historical earthquakes, and the average repeat-times and other characteristics of the known faults. The underlying model is provided by plate Tectonics, which predicts a direction and rate of strain accumulation that has been confirmed by direct geodetic measurement, and rheological models, which enable one to predict the response of the rocks of the region to large strains.

\section{BOUNDARY CONDITIONS}

First, we assume that the theory of Plate Tectonics provides a strain Boundary Condition; that is, at wellington the Pacific Plate is moving almost due west relative to the Australian Plate at about $50 \mathrm{~mm} / \mathrm{a}$, and this causes the rocks of the region to be strained with the axis of relative horizontal compression east-west. This strain accumulation is the direct or indirect (through intermediate stages of deformation) cause of all the shallow earthquakes in Wellington. The accumulated rate of seismic strain release cannot exceed this value (but it could be less if the strain caused some permanent, plastic deformation of the rocks).

\section{5}

Second, of the historical earthquakes to affect the region, that of 1855 is undoubtedly the largest and most important. Indeed the others (1848?, 1904, 1942) would have had seismic moments about an order of magnitude less than 1855 and will not be considered here.

Available data will be inadequate to provide an unambiguous assessment of the size and sense of the 1855 fault movement. It is clear, however, that the area between the Wairarapa Fault and the west coast south of Porirua harbour was uplifted; the maximum uplift of $2.5 \mathrm{~m}$ occurring at the axis of the Rimutaka Range. The uplifted area was not less than about $30 \mathrm{~km}$ by 40 $\mathrm{km}$. Circumstantial evidence also points to an accompanying (dextral) movement on the Wairarapa fault, and there is evidence of repeated movements of $11 \mathrm{~m}$ on this fault.

Accordingly, it is assumed that (i) the 1855 earthquake caused a $11 \mathrm{~m}$ dextral offset of the Wairarapa fault (strike $\mathrm{N} 4 \mathrm{O}^{\circ} \mathrm{E}$ ), (ii) the uplift was due to a thrust component $V$ on a fault dipping at $\theta^{\prime \prime}$ with the same strike as the wairarapa fault, and (iii) the (combined) horizontal slip direction corresponds to the Plate Tectonic convergence direction $\left(\mathrm{N} 90^{\prime \prime} \mathrm{E}\right)$. Support for this last assumption comes from Wellman's (1969) finding that the true tilt direction at cape Turakirae is N266" $\pm 1^{\prime \prime} \mathrm{E}$.

(i), (ii) and (iii) imply that

$$
\begin{gathered}
40+\tan ^{-1}(\mathrm{~V} \cos \theta / 11)=90 \\
\text { or } \mathrm{V} \cos \theta \approx 13 \mathrm{~m}
\end{gathered}
$$

If the thrust came close to or broke the surface, the vertical component $V \sin \theta$ can be equated to the maximum uplift, otherwise it will exceed it (see e.g., Haines and Darby, 1987)

$$
V \sin A>2.5 \mathrm{~m}
$$

Thus $\tan \theta>0.18$ i.e. $\|>10$ and $\mathrm{V}>13 \mathrm{~m}$, and the slip $\mathrm{u}$ is given by

$$
u=\sqrt{ }\left(11^{2}+v^{2}\right) \geq 17 \mathrm{~m} \text {. }
$$

The horizontal extent of the thrust will be about equal to the width of the uplifted region, and if the dip is shallow this can be equated to the fault width.

$$
\mathrm{W}>30 \mathrm{~km}
$$

Taking (for the moment) the fault length $\mathrm{L}$ as $40 \mathrm{~km}$, a lower bound for the seismic moment is given by

$$
\begin{aligned}
\text { Mo }=\mu \mathrm{uLW} & \geq 3 \times 10^{10} \times 17 \times 40 \times 10^{3} \times 30 \times 10^{3} \\
& =6 \times 10^{2} \mathrm{Nm} ;
\end{aligned}
$$

this corresponds to a Moment Magnitude (Mw) of 7.8. This is the size of the 1931 Napier earthquake, and is thus a very credible lower bound. The moment can be increased by increasing any or all of the slip, fault width or length; however, the ratio of the slip to fault length is implausibly large (static stress drop $\mu \mathrm{u} / \mathrm{L}=130 \mathrm{Bar}$ ) and it seems that the fault length is grossly underestimated at $40 \mathrm{~km}$. Moreover, the vertical movement of the Wairarapa fault in 1855 suggests that $V$ sin $\theta$ cannot much exceed $2.5 \mathrm{~m}$. If a more realistic fault length of $130 \mathrm{~km}$ is assumed (e.g. Grapes, this collection), the moment increases to 2 $\times 10^{21} \mathrm{Nm}$, and $\mathrm{MW}$ becomes 8.1 .

The following conclusions can be drawn.

(i) If the slip vector direction was similar to the plate tectonic convergence direction, then the 1855 earthquake must have been an oblique thrust at moderate to low angle. A listric thrust reaching the surface at the Wairarapa fault is a plausible 


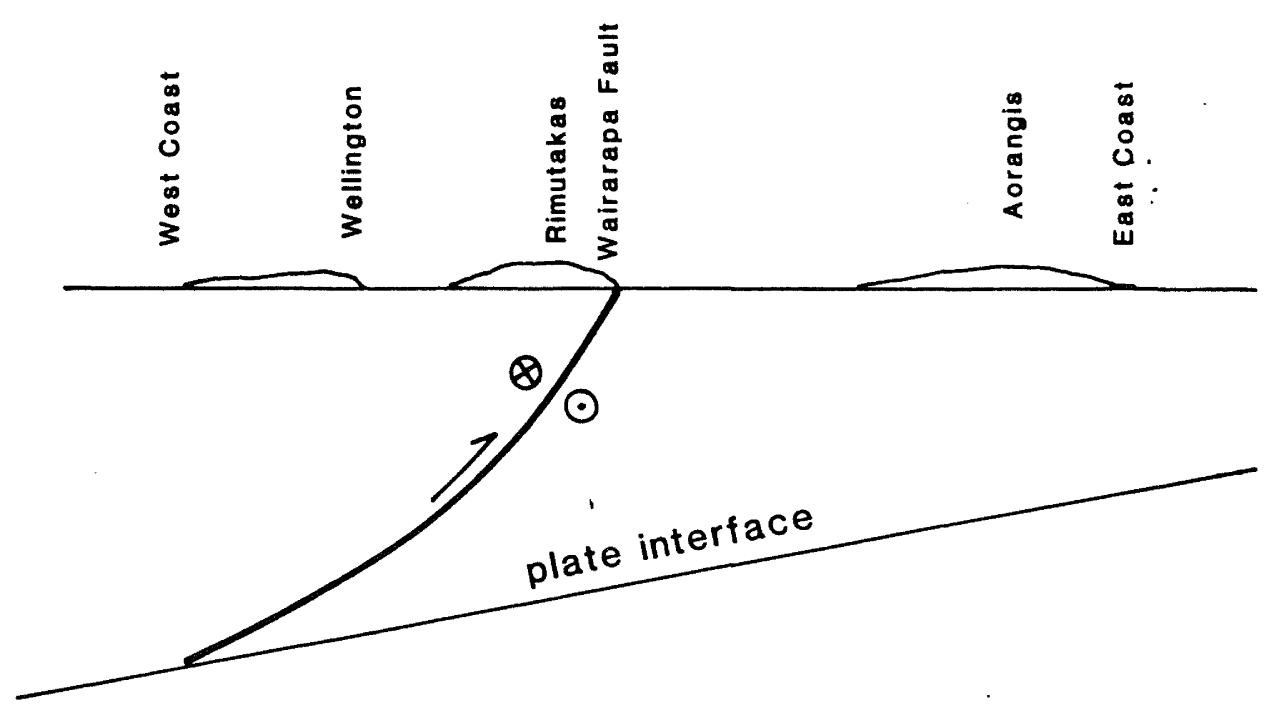

FIGURE 25. CARTOON MODELLING OF 1855 FAULTING.

model (Fig. 25). The observed uplift could not have been due to an subduction thrust event: the interface is too deep and the wavelength of the uplift produced by a subduction thrust would be greater than that observed.

(ii) The 1855 earthquake thus appears to be similar in its faulting characteristics to the 1931 Napier earthquake (Haines \& Darby, 1987).

(iii) It would appear from consideration of the seismic moment bound that there was scarcely any capacity for a thrust event on the plate interface in 1855. There is thus no evidence from historical seismicity for subduction thrust earthquakes at Wellington. Moreover, the Holocene uplift of the Rimutakas and, presumably, the Aorangis can be accounted for by moderate to shallow thrusts that have "captured" existing strike-slip faults.

\section{A MULTIPLE FAULT RECURRENCE MODEI}

It will thus be assumed that the family of four known major faults plus at least one fault offshore to the east (Wellman's "Cape Palliser" fault), and perhaps one to the west (Wairau?/Kapiti fault) are responsible for all major Wellington Region earthquakes. What is the coupling between these faults? It has already been assumed that the loading stress is provided by the Australian/Pacific Plate movement. For simplicity, only the horizontal strain component will now be considered: this is equivalent to $30-35 \mathrm{~mm} / \mathrm{a}$ parallel to the strike of the faults $\left(\mathrm{N} 40^{\circ} \mathrm{E}\right)$, distributed across $100+\mathrm{km}$.

Let us assume that a major event on one of these faults has just occurred (e.g. 1855).
The major strain drop at the fault would instantaneously distribute itself throughout the region if the rocks were perfectly elastic. However, depending on the amount of anelasticity, the strain redistribution will take a period of a few months to a few years (Fig. 26). During this time strain from plate movement will continue to accumulate, and there is thus a slightly increased probability of a major event on another fault during the period of redistribution. This possibility will not be considered further at this stage, and it is assumed that after a decade at most, the strain anomaly caused by the major event has been distributed throughout the region. At this stage, the system will have no memory of the location of the most recent event. The next event will occur when the stress exceeds the strength of the weakest asperity on any of the faults. This could be on the same fault that last moved.

The average time between major events in the region can now be calculated. Suppose there is a family of $M$ faults and the average times between events on each have been established to be $\mathrm{Ti}(i=1, \mathrm{M})$. In a long period of time $\mathrm{T}$ there will be $\mathrm{Ni}=$ $\mathrm{T} / \mathrm{Ti}$ movements on each fault and a total number of events $\Sigma \mathrm{Ni}$ with an average time $\mathrm{T}$ between events of $\mathrm{T} / \Sigma \mathrm{Ni}=1 / \Sigma(1 / \mathrm{Ti})$.

A full analysis of the statistical properties of $\mathrm{T}$ is beyond the scope of this discussion. All available data should be considered in constructing a statistical model for $T$ of which the most important parameter would be its variance. These data include the average return times referred to and:

(i) The fraction of the plate-tectonic strain that was seismically released ("seismic coupling"); this is assessed by adding up the strain released on all the component faults. It could be used to 


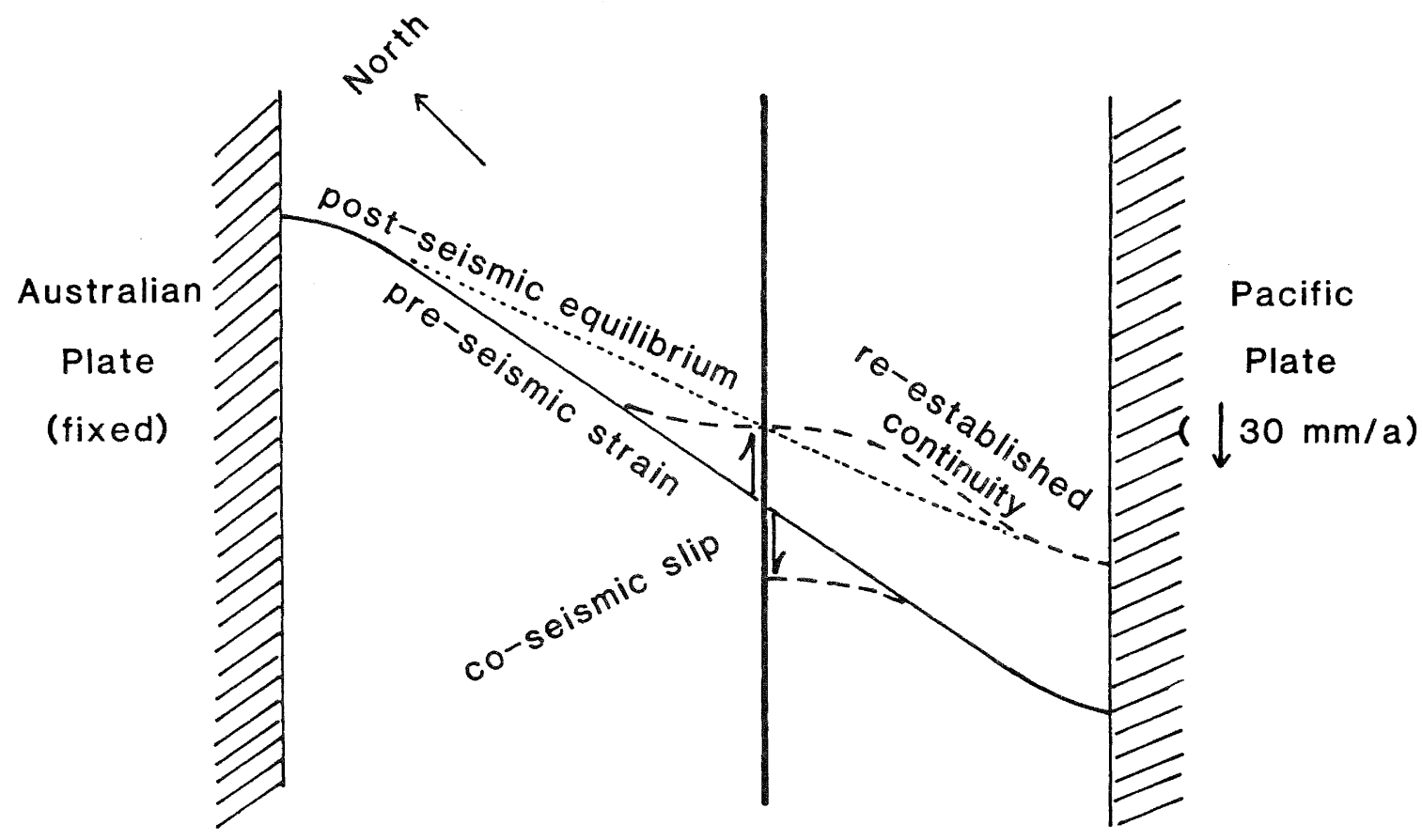

FIGURE 26. PRE-, CO- AND POST-EARTHQUAKE STATE OF STRAIN.

constrain the total number of earthquakes per unit time.

(ii) If the faults do have "characteristic events" (e.g. $12 \mathrm{~m}$ slip on the Wairarapa Fault), then data on these, together with the seismic coupling, could be used to construct a conditional average return time, given the time of occurrence of the previous event (1855).

(iii) As an extension of (ii), if the characteristic events involve rupture on a limited segment of a fault, then the theory could be modified to take this into account. There is prima facie evidence for segmentation in the case of the Wellington Fault.

\section{CONCLUSIONS}

(i) There is no evidence from the limited historical record for subduction thrust events. Nor is there any need for such events to account for the observed deformation. In view of this, one may adopt the hypothesis that all large wellington Region earthquakes produce surface fault breaks on the four (or more?) major onshore faults or on any similar ones offshore.

(ii) A typical large Wellington earthquake is an oblique-thrust event with similar dip- and strikeslip components. (iii) The elasticity of the region containing the faults will ensure that the strain drop of a large earthquake will be redistributed within a few years at the most; thereafter the region will have no memory of which fault was last active.

(iv) The average return time for earthquakes on any fault is the single most important piece of information concerning that fault, and the set of these average times can be used to determine the average time between large events in the region.

\section{REFERENCES}

Grapes, R. 1988. The Wairarapa Fault: displacements and Paleoseismicity. This collection of Abstracts.

Haines, A.J. and Darby, D.J. 1987. Preliminary dislocation models for the 1931 Napier and 1932 Wairoa Earthquakes. Geophysics Div., DSIR Contract Report No. 9. NZ Geological Survey Report EDS 114.

Wellman, H.W. 1969. Tilted marine beach ridges at Cape Turakirae. N.Z. Tuatara $17(2): 82-93$. 


\section{HISTORICAL ASPECTS OF THE 1855 EARTHQUAKE}

G.R. Stevens

NZ Geological Survey

The earth deformation in wellington at the time of the 1855 Earthquake resulted from block tilting along the southern part of the West Wairarapa Fault in the Wairarapa Valley. Movement along the fault line was $2.7 \mathrm{~m}$ vertical and $12 \mathrm{~m}$ horizontal. The entire Wellington region west of the fault was uplifted and tilted, the amount of the uplift decreasing westwards (Fig. 27). Around the Eastbourne area the uplift was $2.1 \mathrm{~m}$; in the Hutt valley $1.8 \mathrm{~m}$ and in the areas around oriental Bay and Lambton Harbour $1.5 \mathrm{~m}$. About $1 \mathrm{~m}$ of uplift occurred at Pauatahanui.

The uplift drained much of the low-lying land adjacent to port Nicholson, in both Wellington city and the Hutt Valley, and exposed shore platforms around the entire harbour coastline. The front of the Hutt delta was extended for a distance of $30-100 \mathrm{~m}$, depending on the amount and extent of sediment deposited offshore prior to the earthquake (Fig. 28).

Before the uplift much of Petone and Lower Hutt was swampy and prone to flooding. The Hutt River was originally a broad tidal estuary, navigable by sea-going schooners as far as Taita and by punt to Maoribank, Upper Hutt. A vast swamp (Te Mome Swamp) covered much of Alicetown and the Awamutu and Waiwhetu swamps occupied substantial areas of Moera, Waiwhetu, Waterloo and Epuni. Shipyards were sited on both the Waiwhetu stream and at the southern tip of Gear Island (Fig. 29).

The uplift increased the gradient in a seawards direction sufficient to drain many of the swamps, and considerably reduced the depths of both the Hutt River and Waiwhetu stream, making them unsuitable for navigation. The changed regime of the Hutt River caused the silting up of the western channel around Gear Island (the main channel prior to 1855) and enlargement of the eastern channel to take the main flow of the river.

Before the 1855 earthquake many of the promontories around port Nicholson were impassable at high tide, but uplift and exposure of shore platforms around the harbour faciliated the construction of roads and railway tracks.

Around Porirua Harbour regional uplift amounted to ca. $1 \mathrm{~m}$. The coastal platforms and intertidal mud flats were extensively exposed and are now largely occupied by roading, houses and pastureland.

Regional deformation, In the form of tilting decreasing towards the north, also affected the Kapiti Coast. Contemporary reports suggest a causal link between such tilting and diversion of the mouth of the Waikanae River for a distance of $1.7 \mathrm{~km}$ along the coast in a northwards direction.
Tsunamis and seiching occurred in the wake of the earthquake. The Wairarapa coastline experienced tsunamis reaching up to $10 \mathrm{~m}$ above high tide mark and contemporary reports record an overtopping of the Rongotai isthmus. Within Port Nicholson, tsunamis reached $6 \mathrm{~m}$ above high tide mark immediately after the main shock, and seiching continued for some 8 hours afterwards, with water levels regularly rising to some $3 \mathrm{~m}$ above high spring tide level and then falling to some $1.3 \mathrm{~m}$ below lowest tide level at intervals of about 20 minutes. 

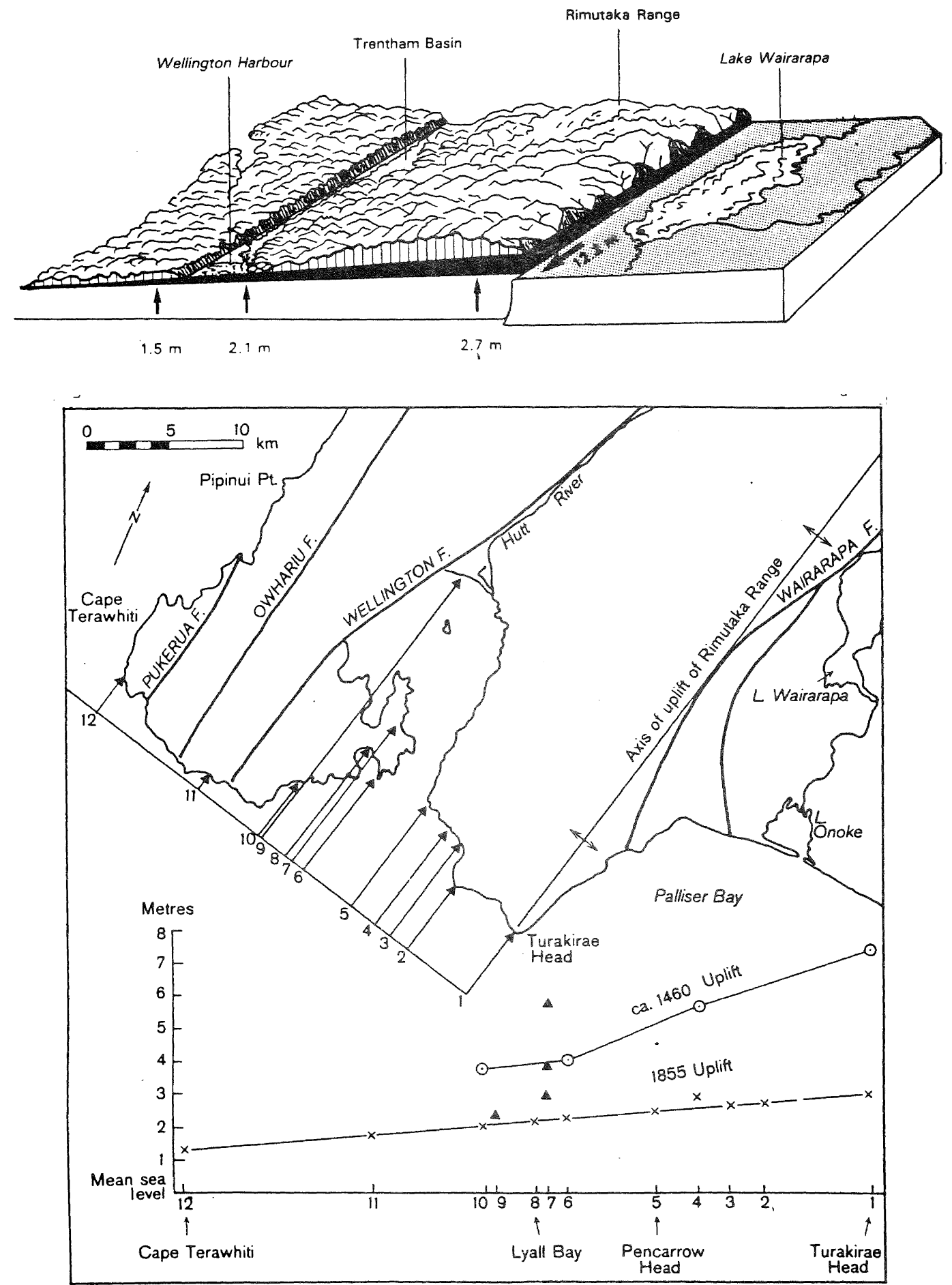

FIGURE 27. REGIONAL UPLIFT ACCOMPANYING THE 1855 EARTHQUAKE. 


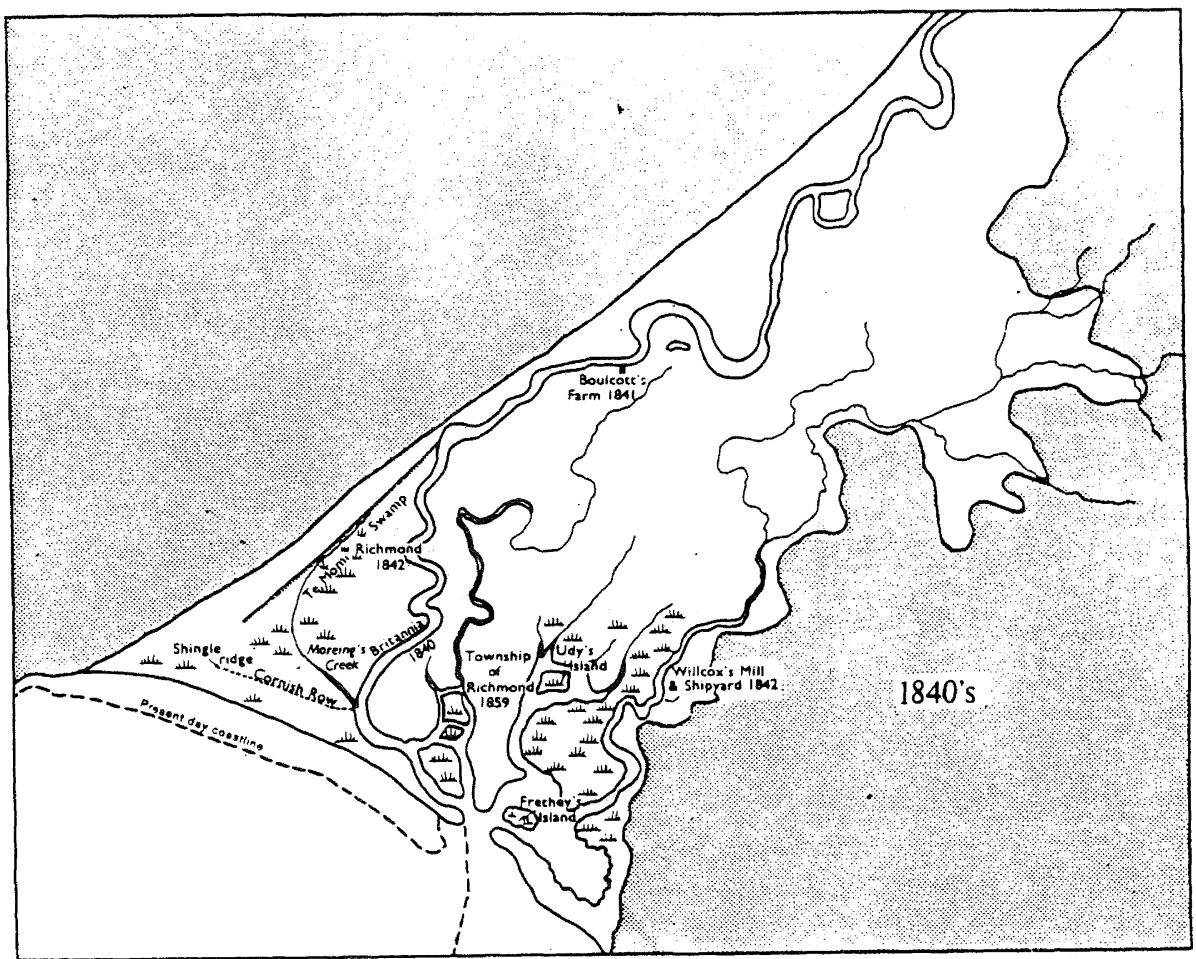

FIGURE 28. THE LOWER HUTT VALLEY IN THE 1840'S.

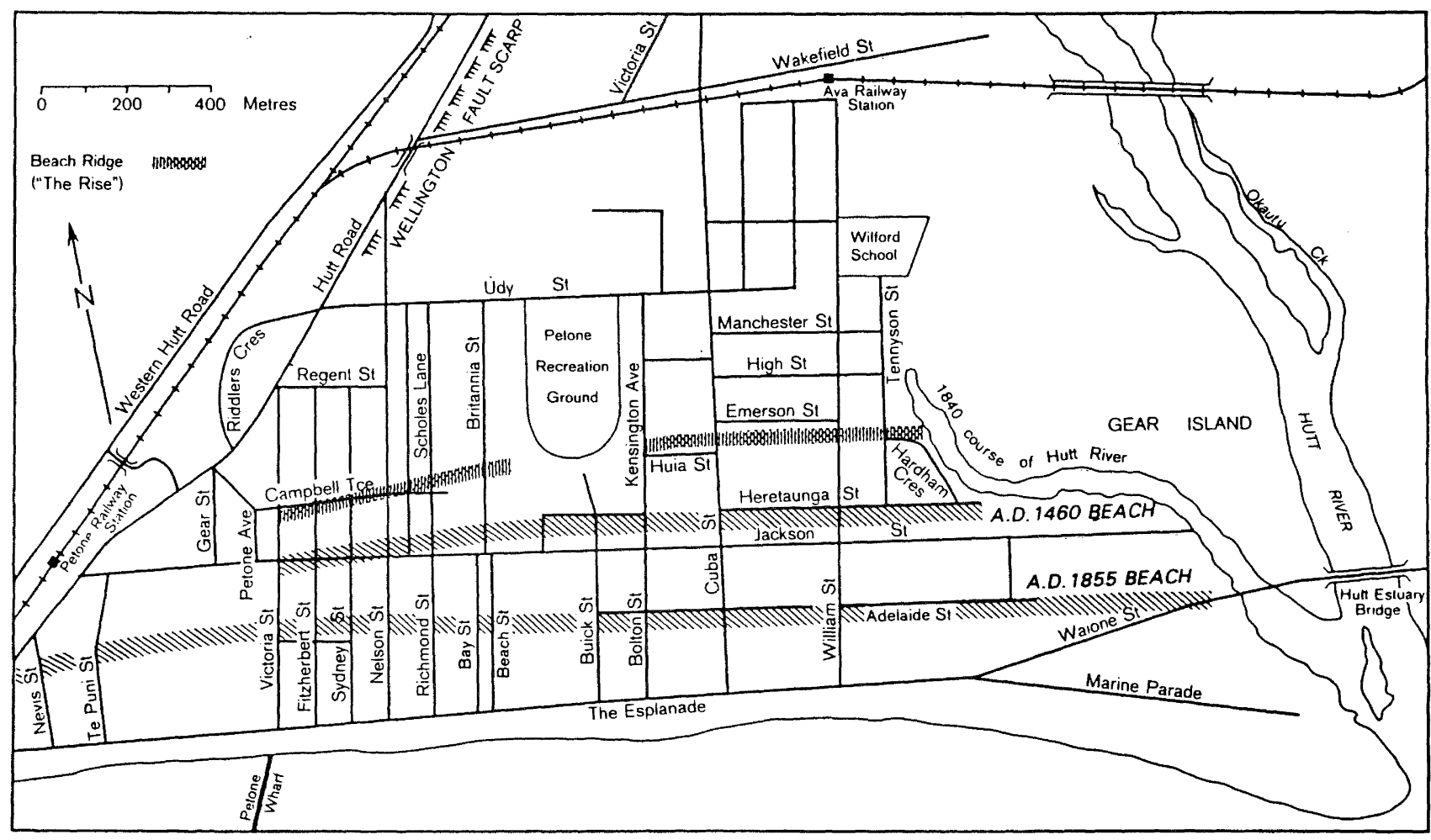

FIGURE 29. BEACH RIDGES IN THE PETONE REGION. 


\section{THE 1942 WAIRARAPA EARTHQUAKES}

Terry H. Webb

Geophysics Division, D.S.I.R.

The 1942 June 24 and August 1 Wairarapa earthquakes have been modelled using longperiod data from Pasadena, California, and La Paz, Bolivia. Such a very limited dataset would usually mean that there was only poor constraint of the focal mechanism, but for these events the rather fortuitous location of the stations with respect to the nodal planes means that there is reasonable constraint.

\section{August 1}

This event shows clear depth phases $\mathrm{pP}$ and sS on the Pasadena records, and it can be modelled as a simple source with a 0.5 , $3.0,0.5$ second trapezoidal time function at $43 \mathrm{~km}$ depth in Robinson's (1986) velocity model. The mechanism shows predominantly normal faulting with one nodal plane dipping $45^{\circ} \mathrm{S}$ to the NW with a strike of $40^{\circ} \mathrm{E}$. The source is thus located within the high-velocity part of the subducted Pacific Plate. Fortunately the Pasadena instrument is fairly reliable in terms of its amplification, so the seismic moment can be estimated. Only the Pasadena $P$ arrival has been used as the $\mathrm{SH}$ wave is quite nodal, and the reliability of the la Paz instrument is unknown. Pasadena is at a distance of $96.4^{\circ}$ from the epicentre which means the $\mathrm{p}$-wave amplitudes are reduced by diffraction around the earth's core. This effect has been compensated for by using the data of Ruff and Kanamori (1983) and amounts to factor of two in amplitude. The derived scalar moment is thus $2 \times 10^{19} \mathrm{~N}-\mathrm{m}$ $(M w=6.8)$. The derived focal mechanism is similar to that derived by Robinson (1986) for his "upper seismic band", with the dip somewhat less, as expected for a position further towards the trench, but the depth more in keeping with the activity in his "lower seismic band".

\section{June 24}

The June event was shallow and is far more difficult to model given the limited dataset. It can not be modelled as a simple source, or even as two events with the same mechanism. A satisfactory fit to the data was obtained using depth-averaged Green's functions to represent a distributed source between 0 and $15 \mathrm{~km}$. This results in a strike-slip solution, with right lateral movement on a NE trending nodal plane. Given the limited data and assumptions involved, other interpretations may be possible. Calculating the moment for this event is problematical because both P-waves may be nodal and the use of a depthaveraged Green's function needs to be considered. The P-wave amplitudes are about half of that of the deep event, while the $\mathrm{SH}$ amplitude is about the same, however the source time function is longer. The change in $\mu$ due to the shallow depth means that the moment is a further factor of 0.4 less than for the deep event. The best we can really say is that the moment is within a factor of two of the deep event. While a right-lateral strike-slip solution striking at $45^{\circ}$ might agree with Robinson's (1986) shallow solutions from the Wellington Network data, it does not explain how this event increased the loading of the subducted Pacific Plate to trigger the deep normal faulting event just over one month later. For this to be the case we would expect this event to have a significant thrust component. This may be determined if a more complete dataset can be obtained. 


\section{UPLIFTS AND EARTHQUAKES IN THE WAIRARAPA FOR THE LAST SIX THOUSAND YEARS}

\section{H.W.Wellman}

Geology Department, VUW, Wellington

The regional (Fig. 30,31) on-shore and part of cook is then directed to the stranded beach ridges at Turakirae Head and coast (fig. 32). For most of the coast there are four stranded beach ridges only, and as far as can be seen they provide a complete uplift record for the last six thousand years or so. Successive uplifts were from $6 \mathrm{~m}$ to $9 \mathrm{~m}$ at the axis of the Rimutaka Anticline and are unlikely to have been restricted to the Turakirae coast. Beach ridges recording successive uplifts have been levelled and averaged for almost the whole length of the coast from Turakirae north-east to Flat Point near Glenburn (Fig. 33). As at Turakirae they cover the last six thousand years or so and they should correlate with those at Turakirae. So far there has been no correlation and this has weakened the argument mentioned above that the Turakirae record is complete. The lack of correlation is because beach ridge $F$ has been included. If it is excluded on the grounds that is is about seven thousand years old and thus older than the others (Fig. 34) then a good correlation can be established for all the Wairarapa beach ridges.

An interpretation of the correlation in terms of successive earthquakes (Fig. 35) will be presented.

If time permits the pseudo-thrust at Wharekahau on the east flank of the Rimutaka Anticline will be compared with the thrust at Ngapotiki on the east flank of the Aorangi Anticline.

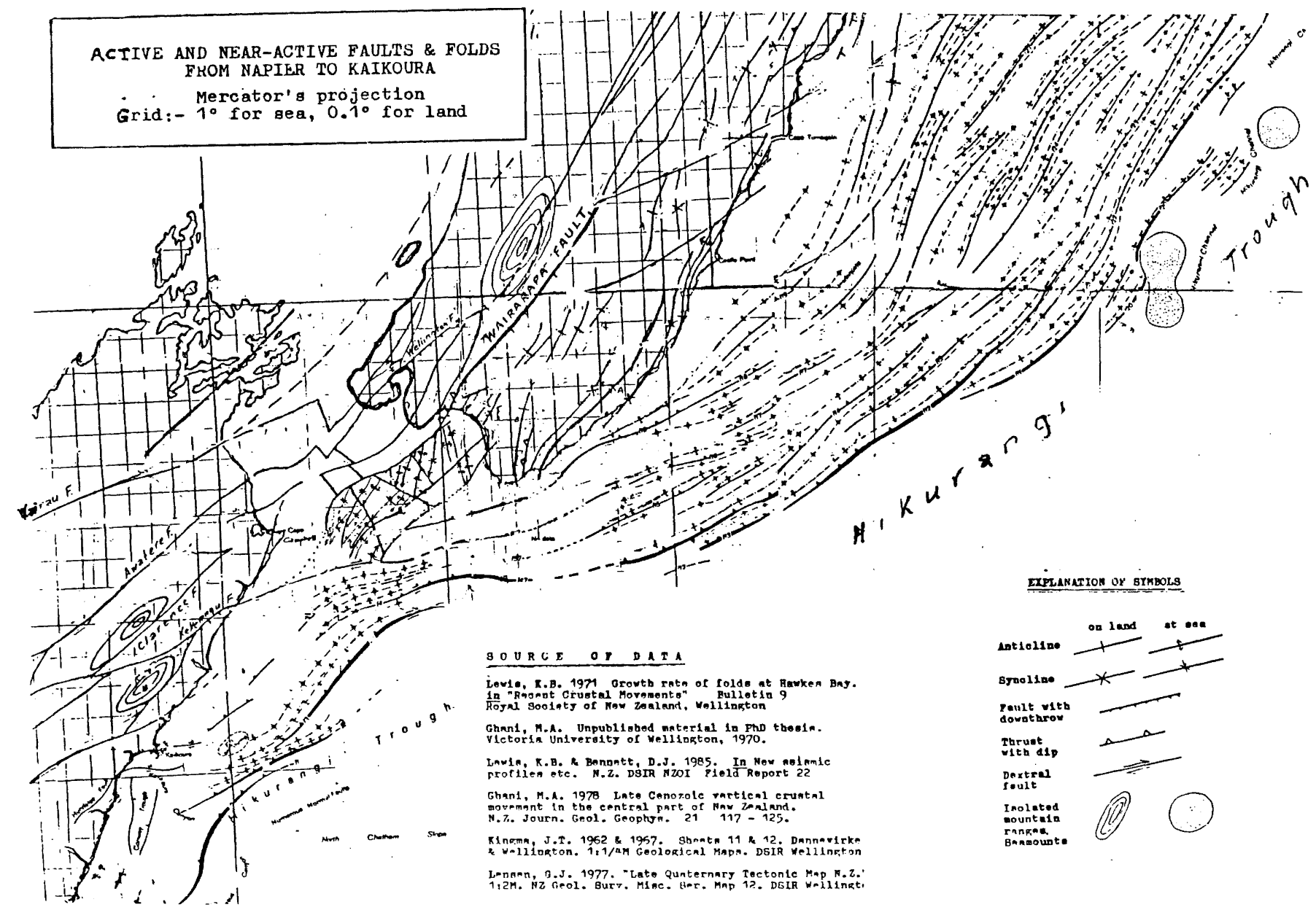

FIGURE 30. AN ATTEMPT TO SHOW ON ACTIVE AND NEAR-ACTIVE Strait with faults and stralt with faults and
A SINGLE MAP ON-SHORE AND OFF-SHORE FAULTS AND FOLDS. The part of Cook folds was thought to be an area of in 1970 . 


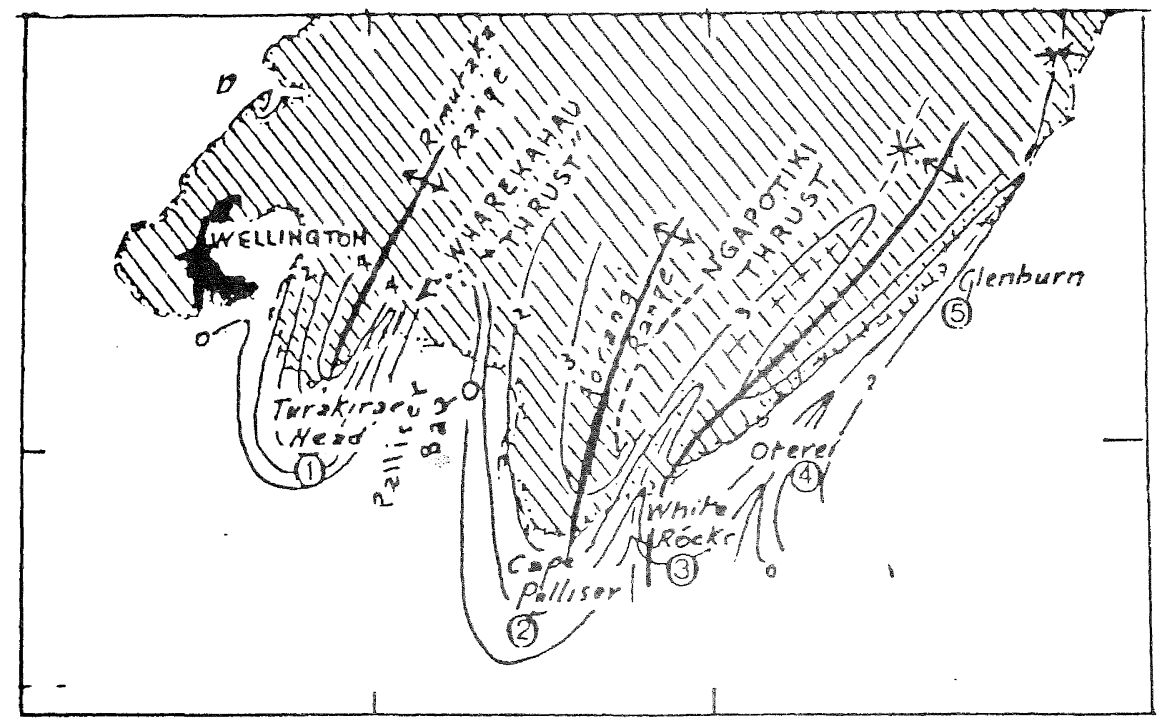

FIGURE 31. SKETCH MAP OF SOUTH COAST OF NORTH ISLAND (CENTRE OF FIG. 30) SHOWING: 1 . uplift rates, 2 . fold axes of active folds, 3 . the position of the Wharekahau "Thrust" and the Ngapot1ki Thrust, and 4. the names and numbers for the coasts that have stranded beach ridges that have been levelled and averaged and here used in the overall correlation shown in Fig. 33.

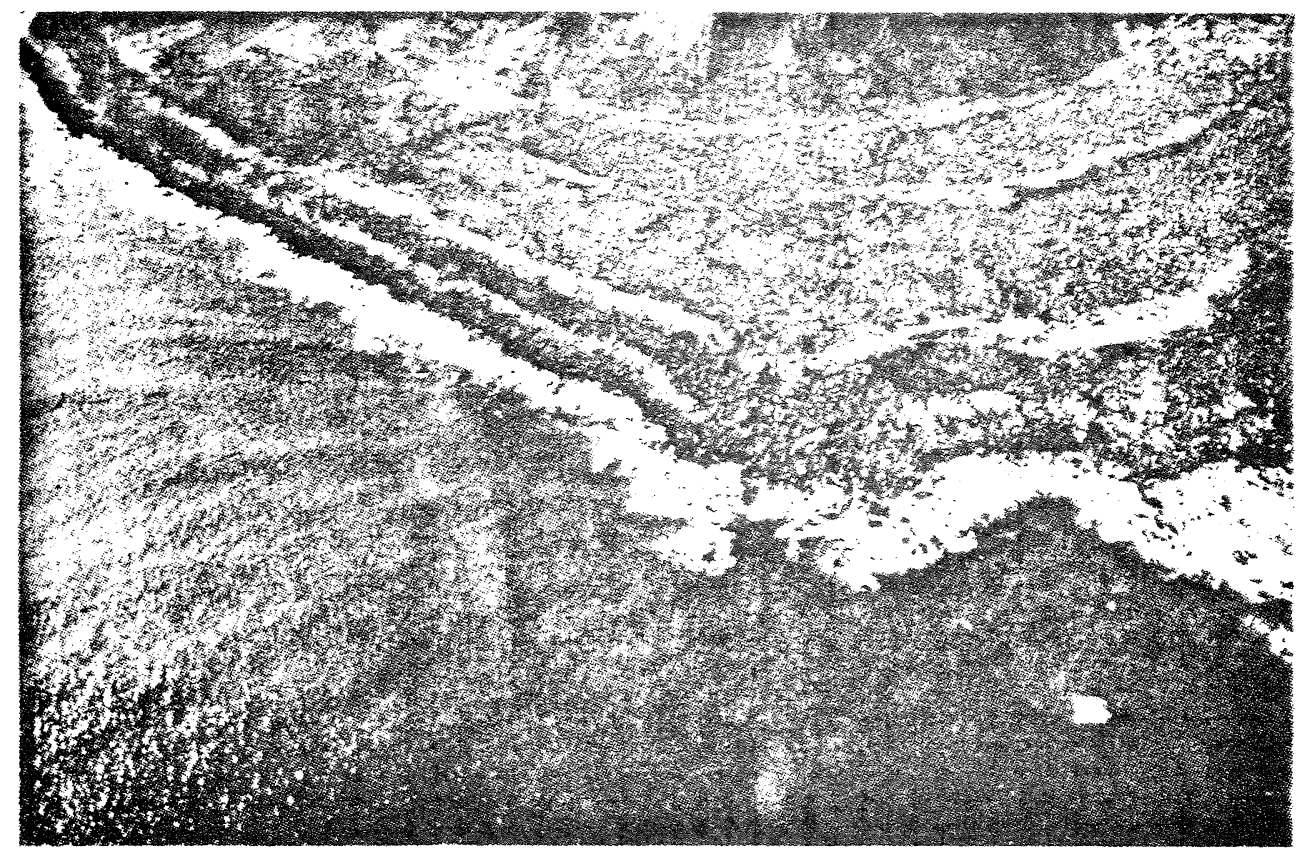

FIGURE 32. OBLIQUE AIR PHOTOGRAPH OF ROCK PLATFORM NEAR TURAKIRAE HEAD. The four beach ridges are $B, C, D$, and $E$. A is poorly defined and is hidden by surf, and $F$ is burled beneath the scree at the foot of the hill at the back. Boulders and rock outcrops up to $3 \mathrm{~m}$ high are scattered over the whole width of the platform. Note the absence of any trace of intermediate beach ridges. 
Peter R. Wood

Earth Deformation Studies Programme NZ Geological Survey, DSIR Lower Hutt

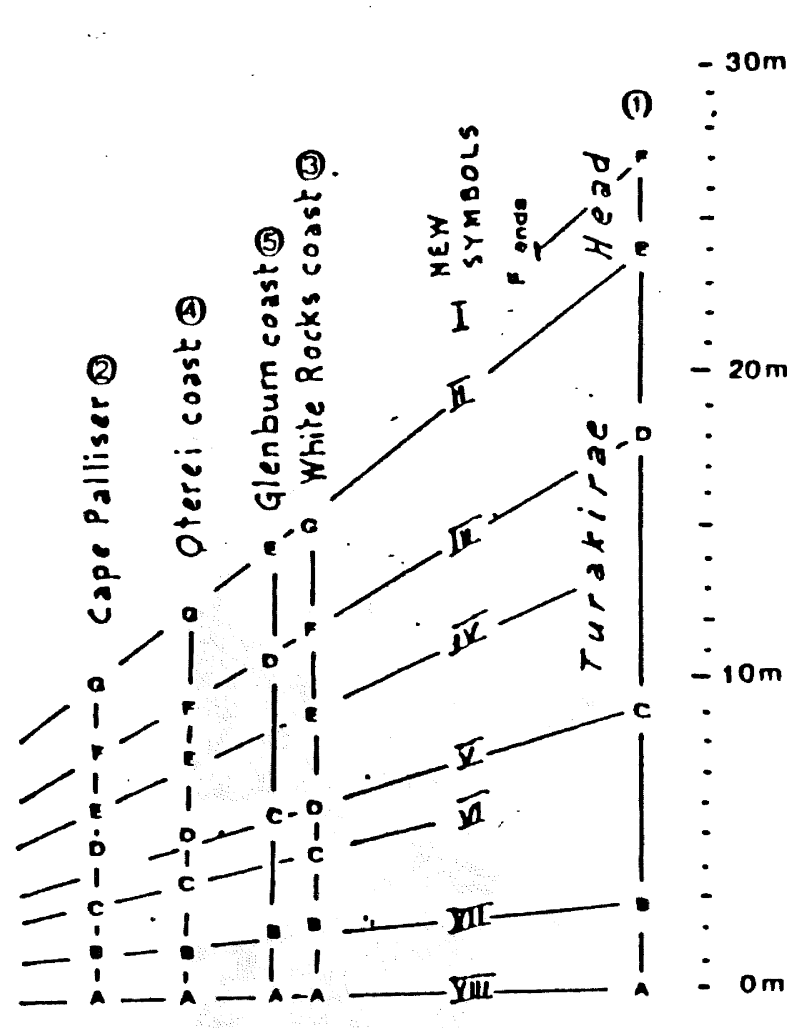

Faulting is integral to the structural development of the Wellington Region. Fault data (location, dip, strike, fault zone width, slip vector and its time variation) is needed to further develop the regions structural history and paleoseismicity. It is also needed, with other geological and geophysical data, for sound judgements of basement conditions and hazard from seismotectonics, including fault rupture of the ground surface, for planning and development purposes.

Fault finding continues to use the old techniques - field observations, airphoto interpretation, drilling - but also (for Wellington) the new - trenching, seismic refraction, seismic reflection (onshore and offshore), ground radar and radon emission. Locating techniques are being tested for urban application, particularly across the wellington Fault at Harcourt Park, Upper Hutt.

The accuracy of fault location need not be high for purely scientific study - except for directing further investigations (eg trenches). It is more critical to accurately locate the marker offset across the fault from which slip vectors are derived. However if fault (fault zone) location is to be considered in urban development then it needs to be known to within 20 metres. It is easier, and less expensive, to utilise such data in the earliest stages of development, rather than later (cf Totara Park with Thorndon, or Porirua City Centre).

In the last few years fault location data has been collected for the Wellington Fault (Te Marua, Emerald Hill, Harcourt Park, Petone, Wellington Harbour, Thorndon and cook Strait); Ohariu Fault (north of Pauatahanui, East branch at Porirua City); and for other faults of the Kapiti coast, within the R26 map area.

FIGURE 33. OVERALL CORRELATION OF THE AVERAGES FOR BEACH RIDGES ON COASTS $1,2,3,4$ AND 5 . The original numbering system $A, B, C$, etc upwards from growing beach ridge of the present day is replaced by a more general one that goes from I for the oldest, from II for the next oldest, and so on to VIII for the growing beach ridge of the present day. In the correlation disregard beach ridge I. Then for beach ridges II to VIII inclusive all 7 are present at coasts $2,3, \& 4$, but only 5 are present at coasts 1 $\& 5$. Note that coasts $2,3, \& 4$ adjoin and form the south end of the North Island. 


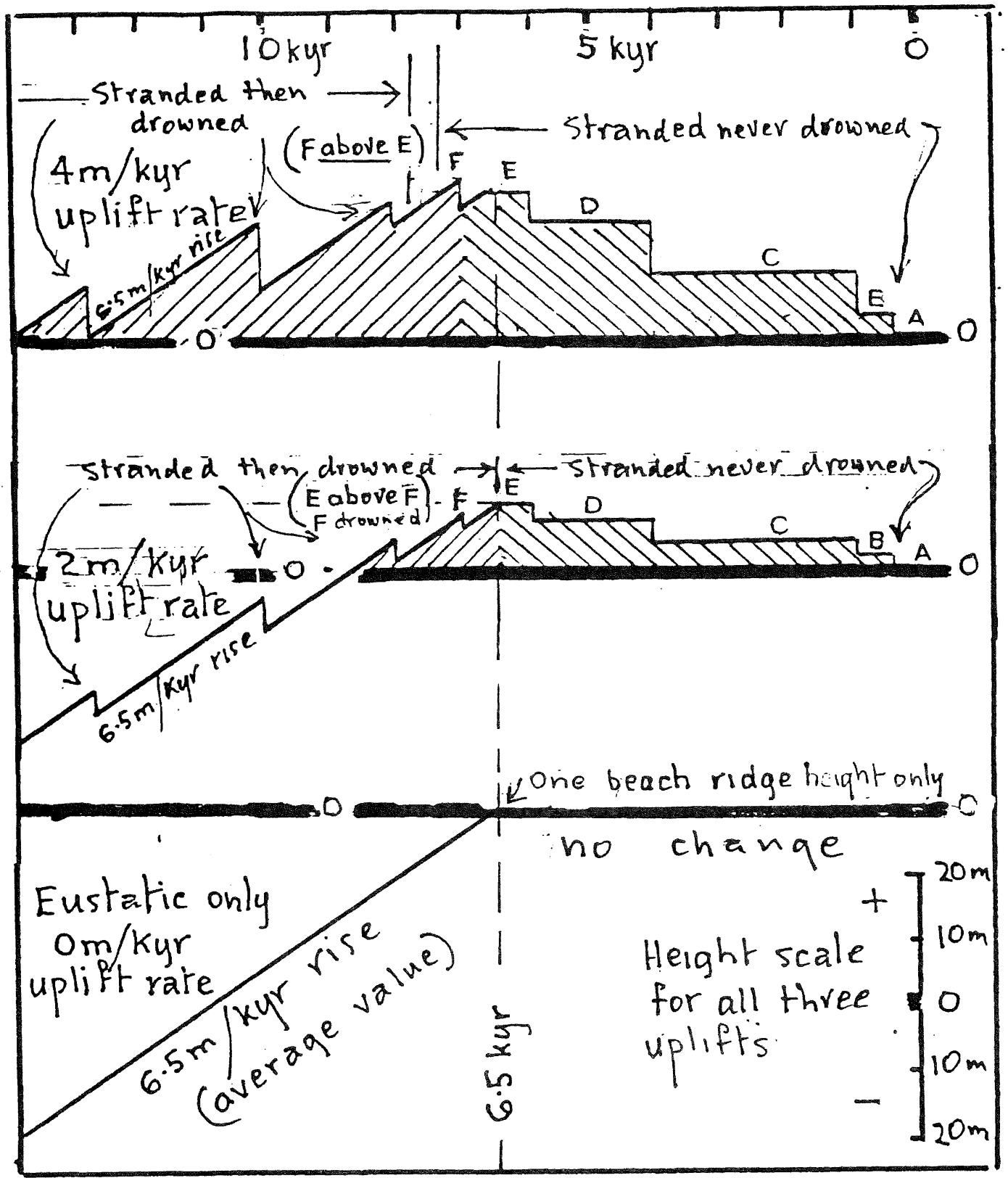

FIGURE 34. EXPLANATION FOR DISREGARDING BEACHRIDGE I (F, TURAKIRAE). Three shoreline displacement curves for Turakirae are shown. The first with a $4 \mathrm{~m} / \mathrm{kyr}$ uplift rate contains "I" as the oldest and highest beach ridge. The second has an uplift rate of $2 \mathrm{~m} / \mathrm{kyr}$ and Beachridge I was stranded but later drowned by the eustatic rise of sea level. Note that the difference in the three curves lies in the amount of uplift, not in the eustatic sea level rise which is the same for all. Accordingly Beachridge I is older than the others and cannot be correlated with them. 


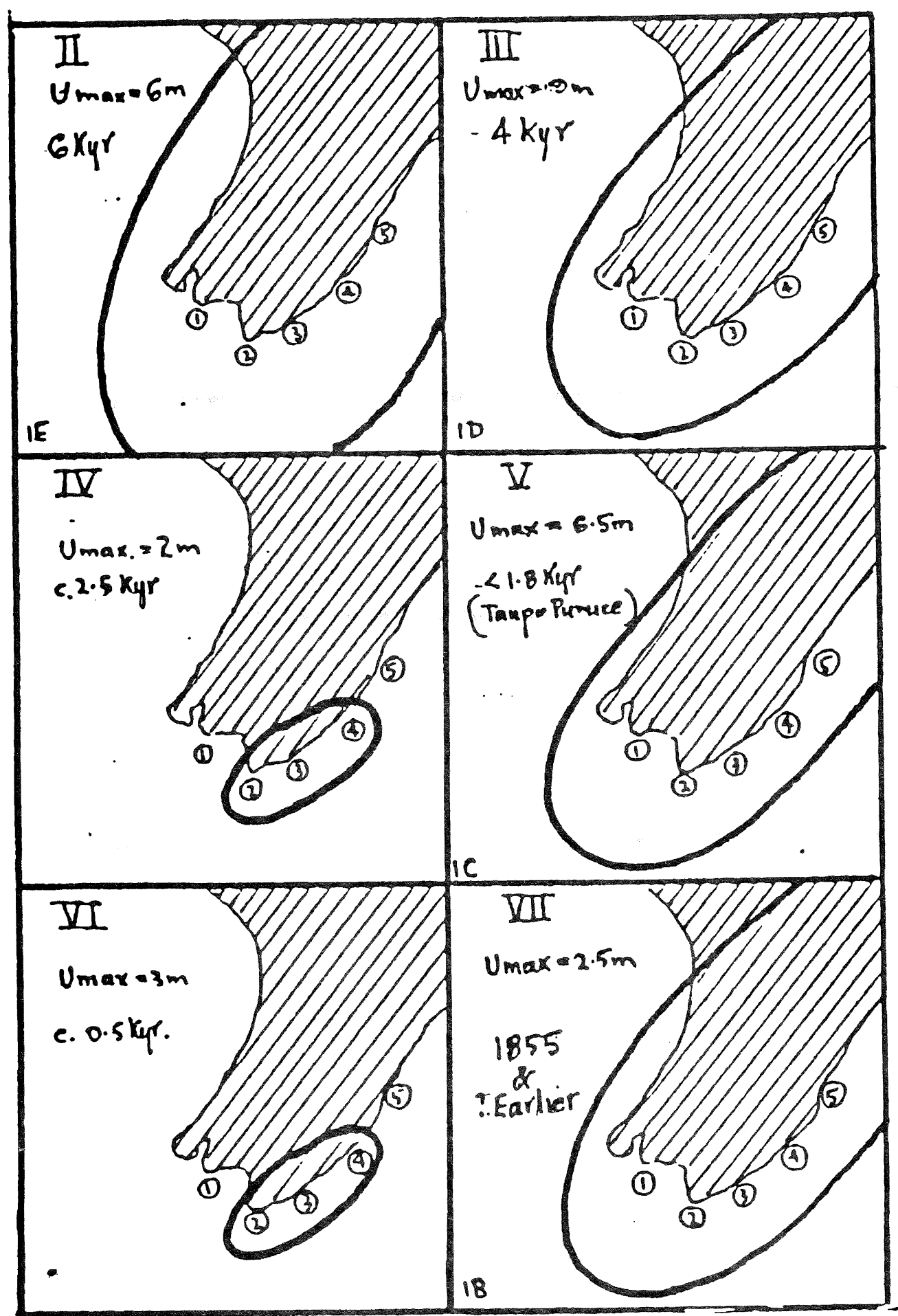

FIGURE 35. SUCCESSIVE UPLIFTS ARE EXPLAINED BY SUCCESSIVE EARTHQUAKES AND SIX EARTHOUAKES ARE THOUGHT TO HAVE STRANDED THE SIX BEACH RIDGES II, III, IV, V VI AND VII, the first, second, fourth and sixth earthquakes uplifting all the coasts and the third and fifth the adjoining coasts at the south end of the North Island only. Thus for the last six thousand years there have been four very large (>M8) and two large (C.M7.7) earthquakes. 